\title{
Saraybosna'nın Şehdî Osmân Efendi Kütüphanesi: Arapça İlimlerine Ait Yazmalar*
}

\section{Kerima Filan**}

\section{$\ddot{\mathbf{O z}}$}

Osmanlı bürokratı olarak bilinen Şehdî Osmân Efendi 1174 (1760-1761) y1lında Saraybosna'da kütüphane kurduğunda bu, Osmanlı devletinin bu bölgesinde müstakil binaya sahip ilk vakıf kütüphanesi oldu. Ana koleksiyonunu oluşturan kitapların sayısı 180 civarında idi. Şehdî Kütüphanesi 1910 yılına kadar hizmet vermiş, 1914 yılında koleksiyonun tümü Gazi Hüsrev Bey Kütüphanesi'ne nakledilmiştir.

$\mathrm{Bu}$ çalışma için Gazi Hüsrev Bey Kütüphanesi'nde korunan yazma eserlerin 17 cilt halinde Katalog'u taranmış, Şehdî Osmân Efendi vakfina ait olduklarına dair bilgi verilen kitapların listesi çıkarılmıştır. Bu çalışmada Arapça ilimleriyle ilgili kitaplar üzerinde durulmuştur. O dönemde ilmî eserleri okuyup anlayabilmek için Arapça bilmek gerektiği görüşünün hakim olduğu bilinmektedir. $\mathrm{Bu}$ durumda Arapça dil bilgisi alanına ait kitapların koleksiyonların yapı taşlarından olduğu söylenebilir.

Şehdî Osman Efendi koleksiyonuna ait Arapça ilimlerine giren kitaplar incelendiğinde önemli bir kısmının Osmanlı medreselerinde okutulan ders kitapları olduğu görülmüsşür. Sarf, nahiv, belâgat olmak üzere Arapça öğretiminin gerçekleştirildiği her üç daldan kitaplara yer verilmiştir. Koleksiyona alınan eserler arasında medreselerde okutulmayan kitapların bulunduğu da tespit edilmiştir. Böylece kaynaklarda anılmayan bir eser bugün sadece Şehdî Kütüphanesi'nin ana koleksiyonunda yer almış nüshasıyla bilinir. Koleksiyonun bir başka özelliği, bir eserin birden fazla nüshasının dahil edilmemiş olmasıdır. Bu koleksiyondan ödünç kitap alınmasının mümkün olduğu sonucuna bizi ulaştıran durumlar da tespit edilmiştir. Çalışmanın bir bölümünde elde edilen bilgilere dayanılarak Şehdî Kütüphanesi’nin kuruluş amacına ulaştığ gösterilmektedir.

Anahtar kelimeler: Osmanlı dönemi, Saraybosna, Osman Şehdî Kütüphanesi, Arapça ilimleri, kitap koleksiyonunun oluşturulması

\footnotetext{
* Araştırma makalesi/Research article. Doi: 10.32330/nusha.910877

** Prof. Dr., Sarayevo Devlet Üniversitesi, Felsefe Fakültesi, Doğu Dilleri ve Edebiyatları Bölümü, Türk Dili ve Edebiyatı Anabilim Dalı, e-posta: kerima.filan@ff.unsa.ba, _Orcid No: 0000-0001-6315-5868

Makale Gönderim Tarihi: 06.04.2021

Makale Kabul Tarihi $\quad$ : 24.12.2021

NÜSHA, 2021; (53): 297-326
} 


\title{
Osman Shehdi-Effendi Library in Sarajevo: Manuscripts in the field of Arabic
}

\begin{abstract}
When the Ottoman bureaucrat Shehdi Osman-Effendi (1760-1761) opened a library in Sarajevo in 1174, it was the first independent library in this part of the Empire. The basic collection comprised about 180 books. Shehdi's Library remained open until 1910, only to be transferred to the Gazi Husrev-Bey's Library in 1914.

For the purposes of writing this paper all 17 volumes of the Catalogue of manuscripts at the Gazi Husrev-Bey's Library were reviewed, and a list of books was composed which are indicated as belonging to the collection of Shehdi's Library. The paper analyses the works in the field of science of the Arabic language. The goal is to examine how the library's stock was established. It is indicated that the majority of those works are those studied at Ottoman madrasas. There are books from all three fields of science of Arabic: morphology, syntax and rhetoric. The analysis shows that the collection also contains the works which were not studied at madrasas. For instance, there is a work in Arabic grammar which is not mentioned in other sources. It is emphasized that there is hardly ever more than a single copy of one work. A reliable piece of information is presented-those books were lent out for reading. These and some other features of the collection discussed in the paper indicate that Shehdi's Library achieved the purposes for which it had been founded.
\end{abstract}

Keywords: Ottoman period, Sarajevo, Osman Shehdi Library, sciences of Arabic, establishing a book collection

\section{Structured Abstract}

When Shehdî Osman-Effendi established a library in Sarajevo in mid- $18^{\text {th }}$ century, it was the first independent library in this part of the Ottoman Empire. With this endowment, the benefactor transferred to Bosnia the practice that had come to life in the Ottoman Empire in the $17^{\text {th }}$ century and evolved in the $18^{\text {th }}$ century as a new incentive to the scientific and cultural life of the Empire. According to the available information, the basic library collection comprised about 180 works. The library remained open until 1910. That was when the library building was torn down to carry out some previously planned construction works. As a new building had never been erected despite all the assurances, the entire collection of books was transferred to the Gazi HusrevBey's Library in 1914.

For the purpose of this paper, all 17 volumes of the Catalogue of manuscripts currently kept at the Gazi Husrev-Bey's Library have been reviewed. A list of books has been composed which were indicated in the 
Catalogue as belonging to the Shehdi Osman-Effendi Library, the proof of which are the library stamps and the list composed on the occasion of transferring the collection. The focus of this paper are the works from the library of Osman Shehdi which are in the field of the Arabic language. There is a wellknown belief that was predominant in the centuries past that in order to read and understand scientific literature one had to possess the knowledge of Arabic. Arabic was taught in madrasas and books in Arabic linguistics were present in all book collections. The aim of this paper is to examine by analysing books in Arabic grammar how the library founders approached their philanthropic activities and how they established the stock in the library they had built.

A careful examination of the works in Arabic linguistics in possession of the Osman Shehdi Library reveals that the majority of those are books used in madrasas for studying Arabic. It has also been observed that there are works among them which can be classified into all three fields of Arabic linguistics: morphology, syntax and rhetoric. The same as when establishing the library stocks at independent libraries consideration had to be taken to represent the books in Islamic sciences in an equal proportion (Erünsal), it may be said that books in specific fields of science were selected so as to cover the entire field. Another feature of the library stock is that the collection mainly did not include several copies of the same book. Out of about thirty books in the field of Arabic grammar, the basic collection of Shehdi's Library contains only three works in just two copies, specifically in the magmuas where they were transcribed along with some other works. Some works which were used as textbooks in madrasas are not present in this collection, but sherhs (commentaries) and hashias (glosses) are, in which scholars commented those fundamental works. Those are commentaries which were studied in madrasas together with the fundamental text.

In addition to those works Shehdi's collection contains works from Arabic grammar which had not been studied in madrasas. This is how we are nowadays familiar with the work entitled Hâşiye 'alâ Imtihâni'l-ezkiyâ, owing to a copy belonging to the basic collection of the Shehdi Osman-Effendi Library.

The paper points to the rare and valuable samples of books in Shehdi's collection, to the transcripts composed close to the time of origin of the fundamental work, and to the places where the books from this collection were transcribed. The least information may be found about the transcribers. Even when the transcript stated the transcriber's name, it is not known who those persons were and why they transcribed books in Arabic grammar. Further, the paper emphasizes an important piece of information that books from this library were lent out for reading. 
That the library established by Shehdi Osman-Effendi was a significant institution in the cultural life in the area is corroborated by the information about donated books which enriched its stock. Entire book collections were donated, as well as individual book samples.

With the Shehdi Osman-Effendi Library Bosnia lived a new cultural practice which was reflected in establishing independent libraries. This novelty brought to Sarajevo by an Ottoman bureaucrat from Rumelia (Akovali) was supported by Sarajevo scholar Kantamiri Abdullah-Effendi by endowing his private collection of books and establishing the second independent library in the city in 1774 .

\section{Şehdî Osmân Efendi ve kütüphanesi}

Bir Osmanlı bürokratı, divan şairi ve Sefernâme müellifi olarak bilinen Şehdî Osmân Efendi Saraybosna'da bir kütüphane kurmuştur. Bu bina, halk arasında geçmişte Hünkâriye, günümüzde Çareva adıyla bilinen İsâ Bey İshâkzâde Camisi avlusunun sol köşesinde idi. ${ }^{1}$

Şimdiye kadar Şehdî Osmân Efendi'ye dair kaleme alınmış çalışmalarda bu kütüphane ile ilgili fazla bilgiye rastlanmaz; genel olarak kütüphanenin kuruluş tarihine dair birkaç çelişkili ifade tekrarlanır. Bir görüşe göre Saraybosna'daki kütüphane için 1171 yılında (15 Eylül 1757-3 Eylül 1758) bir bina yaptırılmıştır. ${ }^{2}$ Diğer yandan, kütüphanenin anıldığ 1 güvenli bir kaynak olan Mollâ Mustafâ Başeski'nin (ö. 1223/1808-09) Mecmûa'sında binanın inşa tarihi açık bir şekilde 1174 yılı (13 Ağustos 1760-2 Ağustos 1761) olarak verilmiştir: Akovalı 'Osmân Şehdî Efendi İslâmbol'da ricâl iken Hümçâriye'de ${ }^{3}$ kütüb-hâne binâ eyledi, sene 1174. Mollâ Mustafâ'nın kayda geçirdiği 1174 tarihi kütüphane binasının inşa edildiği değil, hizmete açıldığı (ya da açık olduğu) tarih de olabilir. Vakfedilerek Şehdî Kütüphanesi'ne kuruluş döneminde konulan kitaplar 1173 (25 Ağustos 1759-13 Ağustos 1760) tarihli vakıf mührünü taşıdıklarına göre kütüphanenin o tarihte ya da ertesi yıl hizmete açılmış olabileceğini düşünüyoruz. ${ }^{4}$

Her hâlükârda bu kütüphanenin açılışı Saraybosna halkı arasında yankı yapmıştır. Bunun en iyi göstergesi, Мecmua'sında günlük olayları kayda geçiren Mollâ Mustafâ'nın bu kütüphanenin kuruluşunu zikretmiş olmasıdır. Şehdî Kütüphanesi o dönem Saraybosna'da müstakil binaya sahip ilk vakıf kütüphanesi olarak dikkat çekmiş olmalıydı. Ana koleksiyonunu oluşturan kitapların sayısı 180 civarındaydı. Bu bilgiyi bize aktaran Šabanović (1973, s. 488), koleksiyonda bir âlim tarafından seçilmiş, İslâm kültürünün çeşitli dallarına ait birbirinden değerli eserlere yer verildiğini ileri sürmüştür. Daha sonra yapılan bağışlarla Şehdî Kütüphanesi'nde kitap sayısı artmıştır. Saraybosna kadısına ait iki ayrı Şer'iye Sicili'nde bulunan kayıtlardan hareketle 19. yüzyılda Şehdî Kütüphanesi’ne bağış yoluyla gelen bazı kitapların listesine 
ulaş1lmıştır (Bkz. Čar-Drnda, 1990, s. 243-252). Örneğin, 1828 y1lında İsmâîl oğlu Sâlih İzzet Hromo-zâde adında bir kişinin bir Kur'ân-ı Kerîm ile 164 ciltten oluşan kitap koleksiyonunu, 1831 yılında ise Mehmed oğlu Hâfız Osmân Efendi'nin 103 yazma eseri Şehdî Kütüphanesi'ne bağışladıklarını öğrenmekteyiz. ${ }^{5} \mathrm{Bu}$ toplu bağışların yanısıra muhtelif kişiler tarafından tek tek yapılan bağışların da zaman içerisinde Şehdî Kütüphanesi'nin koleksiyonunu zenginleştirdiklerini aşağıda örneklerle göstereceğiz.

19. yüzyılda Bosna bölgesinde değişen hayat koşulları sonucu hizmete kapatılan ya da binaları yıkılan bazı eğitim müesseselerine ait kitap koleksiyonları Şehdî Kütüphanesi’ne nakledilmiştir. Bu durum kütüphanenin Saraybosna'daki ilim-kültür hayatında önemli bir role sahip olduğuna işaret etmektedir. Örneğin, Avusturya-Macaristan Hükümeti tarafından 1879 yılında Saraybosna'da başlatılan nehir yatağında düzenleme çalışmaları sebebiyle Hacı Abdülkerîm Efendi Sîmzâde Medresesi'nin binası yıkılmış, kitap koleksiyonu Şehdî Kütüphanesi'ne taşınmıştı. ${ }^{6}$ Medresede, 1189/1775'teki kuruluş döneminde derslerde kullanılan kitapların bulunduğu tahmin edilebilir. Bu eğitim kuruluşunun ana koleksiyonuna dair daha fazla bilgi bulunmamaktadır; ancak daha sonraki yıllarda Saraybosna sakinlerinden Hac1 Abdülkâdir Muzafferî'den önemli bir kitap bağışı gelmiştir. Şer'iye Sicili'nde kaydedilen 11 Cumâziye'l-âhir 1207 (24 Ocak 1793) tarihli vakfiyesine göre Muzafferî, müderris ve öğrencilerin yararlanması amacıyla Sîmzâde Medresesi için 74 cilt bağışlamışırı. ${ }^{7}$ Şer'iye Sicili'inin aynı yerinde bağışlanan kitapların okuma salonuna yerleştirilip ihtiyaç sahiplerinin istifadesine sunulduklarını belirten bir kayıt yer almaktadir.

1879 y1lında şehirdeki imâr çalışmalardan dolayı Abdullâh Kantamirî (ö.1188/1774) tarafından 1189/1774 y1lında kurulmuş kütüphanenin binası da yıkılmış, ${ }^{8}$ koleksiyonu Şehdî Kütüphanesi'ne taşınmıştır. Kantamirî Abdullâh Efendi, müderrislik yaptığı Mısrîzâde Medresesi ${ }^{9}$ yakınında küçük bir bina yaptırmış, sahip olduğu 118 ciltlik kitap koleksiyonuyla müstakil bir kütüphaneyi kurmuştu (Bkz. Fajić, 1987, s. 15-36).

Bunların yanısıra Eyni Bey Mektebi adıyla bilinen bir kitap koleksiyonunun Şehdî Kütüphanesi'yle birleştirildiği bilinir. Hünkâriye Camisi'nin karşısında 1605 yılında hizmete açılan Eyni Bey Mektebi 19. yüzyılın ortasına kadar öğrenci yetiştirmiş, Saraybosna'nın önemli öğretim kurumlarından biri olmuştur (Mujezinović, 1974, s. 43). Kitap koleksiyonunun oluşturulması hakkında bilgi bulunmadığı hâlde, 1836 yılında Travnik kasabasının sakinlerinden İsmâîl oğlu Hâcî İbrâhîm Ağa Fazlîzâde'nin Eyni Bey Mektebi için 171 ciltlik bir koleksiyon bağışladığı bilinir. Bundan birkaç sene sonra Eyni Bey Mektebi hizmete kapandığında Hâcî İbrâhîm Ağa Fazlîzâde'nin kitap koleksiyonu da Şehdî Osmân Efendi Kütüphanesi'nde yer bulmuştur. 
Şehdî Kütüphanesi 1910 yılına kadar hizmet vermiştir. 20. yüzyılın başında Meclis-i Ulemâ için yeni bir binanın yapılmasına karar verildiğinde, yer olarak Îsâ Bey İshakzâde Camisi'nin avlusu tercih edilmiştir. Bu karar Şehdî Kütüphanesi'nin yok olmasına neden olmuştur - kütüphane binası yıkılmış, kitapların yeni yapılacak binanın bir bölümüne yerleştirilmesi planlanmıştır. ${ }^{10}$ Halbuki, koleksiyonun tümü 1914 yılında Gazi Hüsrev Bey Kütüphanesi'ne ${ }^{11}$ nakledilmişti. Kütüphane o sırada Gazi Hüsrev Bey Camisi'nin bitişiğinde 1863 yılında yapılmış bir binada bulunuyordu. Binanın, sayısı artan kitap koleksiyonu için yeterli olmamasından ve kullanıcıların ihtiyaçlarını karşılayamamasından dolayı, kitap koleksiyonu için yeni bir mekân bulmak gerekiyordu. Bunun üzerine Meclis-i Ulemâ binasının bir bölümü GHBK için tahsis edilmiş, böylece Şehdî Kütüphanesi'nin koleksiyonu 20. yüzyılın başında planlandığ halde yerleştirilemediği binaya GHBK'yle birlikte taşınmıştır. ${ }^{12}$ Şehdî Osmân Efendi'nin yaptırdığı kütüphane binası yıkıldığında, giriş kapısının üzerinden kitabe sökülüp Meclis-i Ulemâ binasının duvarına konulmuştur. Hâlen aynı yerde durmaktadır. ${ }^{13}$

\section{Şehdî koleksiyonu'nda sarf, nahiv ve belâgat ilimlerine ait kitaplar}

\section{Kaynak ve yöntem}

GHBK'nde korunan yazma eserlerin kataloglanması tamamlanmış ve Katalog 17 cilt halinde yayımlanmışır. El yazmalarının bibliyografik künyelerinde GHBK'ne nereden ve nasıl geldiklerine dair bilgiye yer verilmiştir. Katalog'un bütün ciltlerini tarayarak Şehdî Osmân Efendi vakfına ait oldukları belirtilen kitapların listesini çıkardık. Listede çeşitli ilim dallarına ait kitaplar yer almaktadır. Katalog'daki yazmalar tasnifini takip edersek şöyle bir çeşitlilik ile karşılaşırız: Kur'ân-i Kerîm, tefsîr, akâid, hadîs, usûl-i fikıh, fikıh, fetvalar, farâ'iz, ahlâk, edebiyât, felsefe, mantık, târîh, sarf, nahiv, belâgat, tasavvuf. ${ }^{14}$ Anlaşılan o ki dönemin diğer koleksiyonlarında olduğu gibi yazmaların en önemli kısmı ilâhiyat alanına girmektedir. ${ }^{15}$

$\mathrm{Bu}$ çalışmada sarf, nahiv ve belâgat ilimlerine giren kitaplar incelenip Şehdî Koleksiyonu'nun bazı özellikleri gösterilmeye çalışılacaktır. Bu eserler Arapça eğitimi için kullanılmıştır. Medreselerde İslâmî ilimler dallarında okutulan bütün eserlerin ortak dili olduğundan Arapça daha ilk aşamada öğrencilere öğretilmekteydi. O dönemde ilmî eserleri okuyup anlayabilmek için Arapça bilmek gerektiği görüşü hakimdi; dolayısıyla Arapça dil bilgisi alanında başvuru kaynakları da kütüphane koleksiyonlarına dahil edilmiştir. Çalışmanın amacı Arapça dil bilgisinin çeşitli dallarına ait eserlerin Şehdî koleksiyonunda yer alıp almadığını, bu eserleri ne derecede dengeli bir şekilde ihtiva etmiş olduğunu incelemektir. Bu anlamda Şehdî koleksiyonuna dahil edilmiş Arapça dil bilgisi konulu eserlerin o dönemde Arapça öğretiminin ihtiyaçlarını nekadar karşılayabildiği sorusuna cevap aranacaktır. Aynı zamanda, bu eserlere bakılarak, İmparatorluğun bir uç bölgesinde müstakil bir 
kurum olan kütüphanenin kurulma amacı ve kitap koleksiyonu hakkında bazı görüşler ortaya koyulmaya çalışılacaktır.

Günümüzde GHBK'nde korunan, esasında Şehdî Koleksiyonu'na ait olan sarf, nahiv, belâgat kitaplarının sayfalarında Şehdî Vakfı'nın 1173 (1759-60) tarihli mührü bulunur. Mühürdeki metin şu şekildedir: Ez-mevkûfât-i Osmân Şehdî Efendi ez-hâcegân-i Dîvân-i Hümâyûn 1173. Bu eserler için Gazi Hüsrev Bey Kütüphanesi Kataloğu'nda Şehdî Osmân Efendi'nin vakfindan bu kütüphaneye geldikleri belirtilmiştir. Ancak, bibliyografik künyesinde "Şehdî Kütüphanesi'nden" ibaresi bulunan kitapların Şehdî Koleksiyonu'na kuruluş devrinden sonraki yıllarda giren eserler olduklarını tahmin ediyoruz. Bu ikinci gruba giren yazmaların bazılarına Şehdî Kütüphanesi’nin 1271 (1854-55) tarihli yeni mührü vurulmuştur. Bazılarında bu mühür görülmez; ancak Şehdî Koleksiyonu'na tahsis olunan mekanda bulunduklarına göre, kataloglanma işlemi sırasında bu kütüphaneye ait oldukları tespit edildiğini düşünebiliriz. Öte yandan, taramada karşılaştığımız bir başka sorun, yukarıda zikredilen İsmâîl oğlu Sâlih İzzet Hromozâde'den Şehdî Kütüphanesi'ne bağış olarak gelen yazmaların Katalog'da Şehdî Kütüphanesi'yle ilişsilendirilmemiş olmasıdır. Bu koleksiyona ait kitapların künyesinde "Hromozâde'nin Vakfı" ibaresi kullanılmıştır. Bütün bunlardan dolayı taramayı Katalog'dan hareketle yaptık; ana koleksiyona ait 1173 (1759-60) tarihli vakıf mührünü taşıyan sarf, nahiv, belagât konularındaki kitapları tespit ettik. Emin olamadığımız durumlarda, yazmaları GHBK'nde bizzat gözden geçirdik ve Şehdî Kütüphanesi'nin ana koleksiyonuna ait olup olmadıkları konusunda tereddüdümüzü gidermeye çalıştık.

Çalışmamızın ikinci bölümünde listede yer alan sarf, nahiv, belâgat alanlarında kitapları değerlendirerek Şehdî Osmân Efendi Koleksiyonu'nun tespit edebildiğimiz bazı özelliklerini ortaya koymaya çalışacağız.

\section{Sarf ilmine ait kitaplar}

el-Emsile el-muhtelife şerhi: 15. yüzyıldan itibaren medrese öncesi, ilk basamak eğitim-öğretiminde yer almış el-Emsile el-muhtelife ismiyle bilinen risale üzerine Dâvûd el-Karsî (ö. 1169/1755-56) tarafından kaleme alınmış Türkçe şerhin bir nüshası bir mecmûada yer alır. ${ }^{16}$ Dokuzu sarf ve nahiv konusunda olmak üzere toplam 15 farklı eser içinde barındıran bu mecmûa hakkında daha fazla bilgi bulunmamaktadır (Jahić, 2000, s. 326) ${ }^{17}$.

el-Maksûd fi't-tasrîf şerhleri: Medreselerde başlangıç (iktisar)-orta rütbesinde sarf alanında başlıca ders kitaplarından biri olarak okutulan elMaksûd fi't-tasrîf üzerine yazılan el-Matlûb fì şerhi'l-Maksûd adlı şerh. Eldeki nüsha hakkında fizikî özellikleri dışında ve varak sayısı (toplam 65) dışında bilgi bulunmamaktadır (Jahić, 2000, s. 14). Müellifi de anonimdir. Bu risalenin GHBK'nde korunan bir başka nüshasında "bu şerhin müellif tarafından 887 
(1482) yılında tamamlandığı" anlamına gelen bir not yer alır (Jahić, 2000, s. 12). Bundan el-Matlûb fì şerhi'l-Maksûd'un 15. yüzylla ait bir şerh olduğu anlaşılmaktadır.

el-Maksûd fi't-tasrîf'in bir başka şerhi Rûhu'ş-şurûh adı altında bilinir. Şarihin kimliği kesin olarak tespit edilememektedir. 17. yüzyılda yaşamış Mehmed el-'Ayşî et-Tirevî (ö. 1061/1650-51) olabileceği tahmin edilmektedir. ${ }^{18}$

et-Tasrîfü̈l- 'izzî şerhleri: İzzeddîn İbrâhîm ez-Zencânî'nin (ö. 653/125556) et-Tasrîfü'l- 'izzî ismiyle tanınan ders kitabı Sadeddîn Mes'ûd Taftâzânî (ö. 791/1388-89) ve Seyyîd Şerîf el-Cürcânî (ö. 816/1413-14) tarafindan yazılmış şerhlerle birlikte Osmanlı medreselerinde yukarı iktisar rütbesinde yıllar boyunca okutulmuştur (Hazer, 2002, s. 288). Her iki şerhin de birer nüshas1 Şehdî Koleksiyonu'nda bulunur.

Taftâzânî tarafından kaleme alınmış Şerh-i Tasrîfü'l-'izzînnin Şehdî Koleksiyonu'ndaki nüshası hakkında bilgi yoktur (Jahić, 2000, s. 134). Tek özelliği olarak ön ve son kapaklarında Farsça birer şiir bulunması söylenebilir.

Tesadüf sonucu olmalı ki Cürcânî tarafından kaleme alınmış Şerh-i Tasrîfü'l- 'izzînnin Şehdî Koleksiyonu'ndaki nüshasının ön kapağında Türkçe bir şiir yer almaktadır (Jahić, 2000, s. 154). Nüshanın ayn yerinde Ahmed b. Murâd şeklinde bir isim yazılı bulunur. Bu kişi kitabın önceki sahiplerinden olabilir. Bir başka sahibinin adı, Anadolu Hüdavendigâr sancağı Tuzla kadılığı Temurci köyünden Mehmed b. İbrâhîm olarak (1a) kaydedilmiştir; aynı varakta Hüseyin b. Hasan adlı bir diğer sahibi bu kitabı 21 dirheme satın aldığını kaydetmiştir. Bu alışveriş kitabın 950 (1543-44) yılında istinsah edilmesinden sonra herhangi bir tarihte gerçekleşmiş olabilir.

Merâhü'l-ervâh şerhi: 13. yüzyılın ikinci yarısı ile 14. yüzyılın başlarında yaşadığı bilinen Ahmed b. 'Alî b. Mes'ûd'un kaleme aldığı Merâhü̈l-ervâh'ın 16. yüzyıldan itibaren ders kitabı olarak kullanıldığı ve et-Tasrîfü'l- 'izzî'den sonra iktisad rütbesinde okutulan bir eser olduğu bilinir (Hazer, 2002, s. 288; Fazlığglu, 2005, s. 143). Üzerine yazılan pek çok şerh ve haşiyelerden, Ahmed Dikgöz'ün (ö. 870/1465-66) Şerh-i Merâhüll-ervâh'ı en çok kullanılanlar arasındadır. Bu şerhin bir nüshası Şehdî Koleksiyonu'na dahil edilmiştir (Jahić, 2000, s. 268). Hakkında daha fazla bilgi bulunmayan eser çok yıpranmış durumdadır.

eş-Şâfiye fi's-sarf ve şerhleri: İbn Hâcib (ö. 646/1248-49) tarafindan kaleme alınmış Eş-Şâfiye fís-sarf medreselerde ileri seviyede okutulmuş bir ders kitabıdır. Şehdî Koleksiyonu'na ait nüshası (ilk adı silinmiş olan) [...] b. Mahmûd tarafindan 1164 (1750-51)'de istinsah edilmiştir (Jahić, 2000, s. 66). 
Eserin Arapça, Farsça, Türkçe kaleme alınan 50'nin üzerinde şerhlerinden ikisinin birer nüshası Şehdî Kütüphanesi'nin ana koleksiyonuna dahil edilmiş̧ir. Bunlarda biri, Osmanlı medreselerinde çok rağbet gören Fahreddîn Ahmed el-Çarperdî'nin (ö. 746/1345-46) Şerhü'ş-Şâfiye'sidir (Jahić, 2000, s. 86). Sayfa kenarlarına düşülen okur notlarından nüshanın çok kullanıldığı anlaşılmaktadır. İstinsahının 1078 (1667-68)'de Şemseddîn b. Nureddîn elErmenakî tarafindan yapıldığı dışında bilgi yoktur.

Diğer şerh Radiyeddîn Muhammed b. Hasan el-Esterâbâdî'nin (ö. 688/1289'dan sonra) kaleme aldığı Şerhü'ş Şâfiye'dir (Jahić, 2000, s. 82). İstinsahının yapıldığı tarih belli değildir; ancak Şehdî Osmân Efendi'nin eline geçmeden önce Mehmed el-Bursevî Serrâczâde'nin ve 1023 (1614-15) yılından itibaren Dervîş Mehmed b. İsmâîl es-Sivasî'nin mülkiyetinde bulunduğunu ön kapaktan okumak mümkündür. Nüshanın sayfa kenarlarında okur notlarına rastlanır.

\section{Nahiv ilmine ait kitaplar}

el-Avâmilü'l-mi'e: Abdülkâhir b. Abdurrahmân el-Cürcânî'nin (ö. 471/1078-79) kaleme aldığ el-Avâmilü'l-mi'e, Osmanlı medreselerinde nahiv ilmi için başlangıç seviyesinde aşağı rütbesinde okutulmuştur. Şehdî Koleksiyonu'nda bulunan nüshası hakkında bilgi yoktur (Jahić, 1999, s. 22).

el-Kâfiye fín-nahv ve şerhleri: İktisar mertebesi orta rütbesinde nahiv ilminde okutulan İbn Hâcib'in el-Kâfiye fí'n-nahv adlı eser en önemli nahiv kitaplarından idi (Fazlıoğlu, 2005, s. 147). Şehdî Koleksiyonu'na dahil edilmiş nüshası 1173 (1759-60) tarihli vakıf mührünü taşımaktadır (Jahić, 1999, s. 306). Bunun dışında nüsha hakkında bilgi yoktur.

Bu kitap üzerine yazılan 100 'den fazla şerh ve haşiye arasında Celâleddîn es-Süyûtî (ö. 911/1505) tarafindan "en başarılısı" olarak değerlendirilen Şerhü'r-râdî 'alâ el-Kâfiye, Râdiyeddîn Muhammed b. Hasan el-Esterâbâdî'nin eseridir. ${ }^{19}$ Söz konusu şerhin Şehdî Koleksiyonu'ndaki nüshası 351 varaktan oluşur. İstinsahı 1034 (1624-25) yılında tamamlanmıştır (Jahić, 1999, s. 351).

Bir başka el-Esterâbâdî de (Rükneddîn Hasan b. Muhammed, ö. 715/131516) el-Kâfiye fi'n-nahv üzerine şerh yazmıştır. el-Vâfiye fì Şerhi'l-Kâfiye adında tanınan bu eser iki nüshasıyla Şehdî Koleksiyonu'na katılmıştır. Bunlardan biri, el yazısından anlaşıldığına göre farklı iki kişi tarafından istinsah edilmiştir; ancak bu kişilerin kimlikleri tespit edilememiştir (Jahić, 1999, s. 355). Kitabı tamamlayan müstensih eserin 243a varağında 857 (1453) tarihini kaydetmiştir. Dolayısıyla, nüshanın 15. yüzyıla ait olduğu anlaşılmaktadır. Eserin başında (yk. 1a'da) yer alan mühürlerden önceki sahiplerinin adlarını Feyzullâh Hâdîzâde ve İsmâîl b. Veliyyeddîn şeklinde okumak mümkündür. Bu nüshanın son kapağında Farsça birkaç beyit kayda geçirilmiştir. 
el-Vâfiye fì Şerhi'l-Kâfiye'nin Şehdî Koleksiyonu'ndaki ikinci nüshası da 15. yüzy1lda çoğaltılmıştır (Jahić, 1999, s. 358). İstinsahını 870 (1465-66)'de İstanbul'da Mollâ Zeyrek Medresesi'nde Halîl b. Yûsuf yapmıştır; bu bilgi 180a'da kayıtlıdır. Bir tarihte nüshanın Ramazân adında bir kişiye, gene bilinmeyen bir başka tarihte de Muhammed Sa'id adlı bir kadının eline geçmiş olduğu ön kapağın içindeki notlardan öğrenilir; ancak bu kişilerin kimler oldukları, nerede yaşadıkları ve ne görev yaptıkları tespit edilememektedir.

el-Kâfiye fîn-nahv üzerine yazılan el-Fevâ'idu'z-ziyấiyye adlı şerh, bilindiği gibi, yazarı Mollâ Câmî'nin (ö. 898/1492) adıyla şöhret bulmuştur. Mollâ Câmînnin Şehdî Koleksiyonu'ndaki nüshası Şerîf Muhammed tarafindan Nurc1 Köyü şeklinde kayda geçirilen bir yerde 1053 (1643-44) yılında istinsah edilmiştir (Jahić, 1999, s. 329). İlk sayfada (1a) adı yazılı bulunan Bekir Efendi kitabın önceki sahibi olabilir.

Ebû İshâk İsâmeddîn İbrâhîm b. Muhammed b. Arabşâh el-İsferâyînî'nin Mollâ Câmî üzerine kaleme aldığı haşiyenin bir nüshası Şehdî Koleksiyonu'nda bulunur (Jahić, 1999, s. 373). Nüshanın başında (yk. 1a'da) müellifin (elİsferâyînînin) ölüm tarihi olarak 944 (1537-1538) yılı kaydedilmiştir. Kaynaklarda el-İsferâyînî'nin ölüm yılı olarak 951 (1544) verildiğinden bu kayıt dikkate değerdir. ${ }^{20}$ Eldeki nüshanın istinsah tarihi belli değildir; ancak 1577 yılından önce tamamlandığı şu kayıtlardan anlaşılır: kitabın iki yerinde, hem ön kapakta hem de1a'da, Hüseyin b. 'Abdulkerîm adında bir kişi 985 yılının Şevvâl ayında (1577'nin sonu) bu kitabı oğlu Pîr Mehmed'in mülkiyetine naklettiğini yazmış, bu kaydın yanına kendi mührünü vurmuştur. Gene la'daki bir başka kayıtta, kitabın 1153 (1740-41) yılında Mustafa b. Mehmed Nâsilcî adında bir şahsın mülkiyetine geçtiği bildirilir. Ön kapakta kitabın önceki sahiplerinden olabileceği Akovalı Mehmed b. Haydar Bey'in adı yazılı bulunur. Ne var ki bu kişilerin hangisinin kitabı Şehdî Koleksiyonu'na bağışlamış ya da satmış olduğunu tespit etmemiz mümkün olmamıştır.

el-Kâfiye fî'n-nahv'in muhtasarı olan İrşâdü'l-hâdî adlı eser, 14. yüzyılın çok yönlü âlimi olarak bilinen Taftâzânî tarafından yazılmıştır. Irşâdü'l-hâdî ders kitabı olarak kullanılmış, üzerine birçok şerh yazılmıştır (Özen, 2011, s. 306). Bunlardan Şemseddîn Mehmed b. Mehmed b. Mahmûd el-Buhârî'nin (ö. 850/1446-47) el-Mürşid adlı şerhinin bir örneği Şehdî Koleksiyonu'nda yer alır (Jahić, 1999, s. 140). Kitap hakkında bildiğimiz tek özellik, bu koleksiyona alınmadan önce İstanbullu Ahmed Durmuşzâde adında kişiye ait olduğudur.

Kâfiye fî'n-nahv'ın bir başka şerhi, Kemâl b. 'Alî b. İshâk adında biri tarafından kaleme alınmıştır, ancak kendisinin ne zaman ve nerede yaşadığına dair bilgi bulunmamaktadır. ${ }^{21}$ Risâle-i 'avnü'l-vâfiye fì şerh-i kitâbi'l-Kâfiye başlığındaki bu şerhin mukaddime kısmında müellif, İbn Hâcib'in Vâfiye'si için bir şerh kaleme almak niyetinde olduğunu, dostlarının ricası üzerine Kâfiye'nin bazı bölümlerini açıklamaya çalışarak Kâfiye şerhini yazdığını dile getirmiştir. 
Söz konusu şerhin Şehdî Koleksiyonu'ndaki nüshası bir Mecmûa'nın başında yer alır (Popara \& Fajić, 2000, s. 18). Mecmûa'da ikinci eser olarak ise Kazvînî'nin (ö. 739/1338) Telhîsü'l-Miftâh'1 bulunur. Telhîs'in 1056 (164647)'da Beşiktaş'ta Sinân Paşa Medresesi'nde, Kâfiye şerhinin de 1055 (1645-46) 'te istinsah edilmiş olduğu belirtilmiştir. İstinsah tarihlerinin yakın olması, her iki eserin aynı yerde çoğaltılıp bir cilt hâline getirildiğini düşündürür. Her hâlukârda Şehdî Vakfi'nın 1173 (1759-60) tarihli mührü mecmuanın bir kaç varağında (1a, 2a, 131a ve 149b) bulunduğuna göre, bu koleksiyona tek cilt halinde girmiş olduğu anlaşılmaktadır.

Bu grupta anılması gereken önemli bir eser de I'râbü'l-Kâfiye'dir. Eserin müellifi bilinmediği gibi, eldeki nüshanın müstensihi, istinsah tarihi ve yeri belli değildir. ${ }^{22}$ I'râbü'l-Kâfiye hakkında kesin bilinen tek husus Kâfiye fín-nahv üzerine yazılmış bir şerh olmasıdır.

İmtihânü'l-ezkiyâ adlı eser, el-Kâfiye fín-nahv ile ilgili olduğundan bu grupta ele alınmıştır. İmtihânüll-ezkiyâ, Mehmed Efendi Birgivî'nin (ö. 981/1573) nahivle ilgili Arapça bir eseridir. Birgivî bu eseri, Kâdî Beyzâvî tarafindan (ö. 685/1286) Lübbü'l-elbâb fì 'ilmi'l-i 'râb adı altında kaleme alınmış el-Kâfiye fìn-nahv'in muhtasarası üzerine bir şerh olarak yazmıştır (Yüksel, 1992, s. 193). İmtihânü'l-ezkiyâ'nın Şehdî Koleksiyonu'ndaki nüshası 1158 (1745-46)'de istinsah edilmiştir (Jahić, 2000, s. 439).

Şehdî Koleksiyonu'nda yer alan Hâşiye 'alâ Imtihâni'l-ezkiyâ adlı el yazması hakkında bilgi yetersizdir. Eldeki nüshaya göre müellifi Muhammed el-Kurdî'dir (1b) (Jahić, 2000, s. 399). Bunun dışında eser hakkında bilgi tespit edilememiştir.

el-Kâfiye fïn-nahv üzerine Türkçe yazılmış şerhlerden Ahmed Sûdî Bosnevî'nin (ö. 1597'den sonra) kaleminden Şerhü'l-Kâfiye'si Şehdî Koleksiyonu'na dahil edilmiştir. Eldeki nüshas 318 varak olup, 1017 (1608-09) y1lında istinsah edilmiştir (Jahić, 2000, s. 471). Ön kapağın içinde 13 Zi'l-hicce 1165 (22 Ekim 1752) tarihinden itibaren Rüşdî el-Hâc Muhammed adında bir kişinin mülkiyetinde bulunduğu kaydedilmiştir.

el-Hulâsatï'l-elfiyye ve şerhi: Cemâleddîn Ebû 'Abdullâh Muhammed b. Abdullâh İbn Mâlik'in (ö. 672/1274) el-Hulâsatü'l-elfiyye adlı eserinde Arapça gramerini sistematik bir şekilde açıklamakta olduğu ileri sürülür (Jahić, 1999, s. 81). Binden fazla beyitin yer aldığı bu eser Elfiyye-i İbn Mâlik adıyla şöhret kazanmıştır. Medreselerde nahiv ilminin orta rütbesinde okutulmuştur. Şehdî Vakfı'nın 1173 (1759-60) tarihli mührünü taşıyan nüshası hakkında ne yazık ki bilgi bulunmamaktadır.

Elfiyye-i İbn Mâlik üzerine Behâeddîn 'Abdullâh b. 'Abdürrahmân İbn 'Akîl (ö. 769/1367) tarafından yazılan şerhin iki nüshası Şehdî Koleksiyonu'na 
dahil edilmiştir. Şerh-i Elfiyye-i İbn Mâlik'in bir nüshasının istinsahı 1059 (1649-50)'da (Jahić, 1999, s. 85), diğerinin ise 1094 (1682-83)'te tamamlanmıştır (Jahić, 2000, s. 377). Her iki nüshanın sayfa kenarlarında okur notlarına rastlanır. Bunlardan daha yeni olan nüshanın, önce Ahmed Fevzî'ye daha sonra Mustafâ b. Fevzî Ahmed Efendi'ye ait olduğu ilk sayfalarda bulunan kayıtlardan okunur. Gene bu nüshanın sonunda (175b) Arapça üç beyit ve bunların tahlili kaydedilmiştir.

el-Misbâh fí'n-nahv'in şerhleri: el-Mutarrizî'nin (ö. 610/1213) yazdığı elMisbâh fî́n-nahv Osmanlı medreselerinde (iktisar mertebesinin yukarısında) ileri başlangıç düzeyinde okutulan bir eserdir. Eserin nüshaları GHBK'nde mevcuttur; ancak bunlardan hiç birinin Şehdî Koleksiyonu'na ait olduğunu tespit edemedik. Öte yandan, Şehdî Koleksiyonu'nda el-Misbâh fî́n-nahv üzerine yazılmış şerhler bulunur.

Bunlardan biri Tâceddîn Muhammed b. Muhammed b. Ahmed elİsferâyînî el-Fâzıl (ö. 684/1285-86) tarafindan kaleme alınmış Zav'u'l-Misbâh muhtasar el-Miftâh adlı eserdir (Jahić, 1999, s. 168). Bu eser aynı yazarın kaleme aldığı el-Miftâh fì şerhi'l-Misbâh adında bilinen kapsamlı bir şerhin kısaltılmış bir nüshasıdır. Eldeki nüshanın sonuna (122a) düşülen kayıttan, Rebiül'âhir 1027 (1618) tarihinde Mustafa b. Yûsuf adında kişi tarafından Bayram Gâzî Medresesi'nde istinsah edildiği bilinir. ${ }^{23}$

el-Misbâh fî'n-nahv'in bir başka şerhi Hulâsatü'l-i 'râb başlığıyla bilinir. Müellifin adı Hacı Baba et-Tosyavî'dir (ö. 870/1465-66). ${ }^{24}$ Hulâsatü'l-i 'râb'in Şehdî Koleksiyonu'ndaki 84 varaklı nüshası Alî b. Abdulgânî tarafindan Zi'lhicce 1040 (1631) tarihinde istinsah edilmiştir (Jahić, 1999, s. 168).

Bunların yanısıra Şehdî Koleksiyonu'nda el-Misbâh fì'n-nahv'in Dîbâce'si üzerine yazılmış bir şerh bulunur (Şerh-i dîbâcetü̈l-Misbâh). Müellifi kesin olarak bilinmemektedir; kaynakların bazılarında Sadeddîn Mesûd Taftâzânî'nin, diğerlerinde Yakûb b. Seyyîd 'Alî Bursevî'nin (ö. 931/1524-25) eseri olduğu gösterilmiştir (Jahić, 1999, s. 103). Şerh-i dîbâcetü'l-Misbâh'in Şehdî Koleksiyonu'ndaki nüshasi zi'l-kadde 994 (1586) tarihinde çoğaltılmış; ancak müstensihin adı silinmiştir (Jahić, 1999, s. 102). Önceki sahiplerinden biri Mehmed Fakîh adında bir kimsedir (yk. 1a). Son kapağının içinde Arapça bir ilâhi yazılıdır.

$\mathrm{Bu}$ eser üzerine el-Banbanî (ö. 931/1524-25) tarafından kaleme alınmış haşiyenin (Hâşiye 'alâ şerh-i dîbâcetü'l-Misbâh) iki nüshası da Şehdî Koleksiyonu'nda bulunmaktadır. Biri hakkında 84 varaktan ibaret olması dışında bilgi bulunmazken (Jahić, 1999, s. 216), diğerinin 1056 yılınin Receb ayında (Ağustos-Eylül 1646) tarihinde istinsah edildiği ve 19 Cemâziye'l-evvel 1119 (18 Ağustos 1707) tarihinden itibaren Ahmed b. Mehmed'in eline geçtiği ilk sayfasındaki notlardan anlaşılmaktadır (Jahić, 2000, s. 399). 
el-Enmûzec fî́n-nahv'in şerhi: Arap dil bilimcisi ez-Zemahşerî'nin (ö. 538/1144) öğrencilerinden Ziyâuddîn el-Mekkîi ${ }^{25}$, hocasının el-Enmûzec fî'nnahv adlı eseri üzerine el-Kifâya fì 'ilmi'l- 'arab başlıklı bir şerh yazmıștır. Şehdî Koleksiyonu'ndaki nüshası 970 (1562-63) yılında İbrâhîm b. 'Alî tarafından istinsah edilmiştir (Jahić, 1999, s. 65). Ön ve son kapaklar içinde kitabın içeriğiyle ilgili notlara rastlanır.

Lübbü'l-elbâb fî 'ilmi'l-i'râb' In șerhi: Müellifi kesin olarak bilinmeyen Lübbü'l-elbâb fì 'ilmi'l-i'râb adlı eser üzerine Nukrekâr (ö. 776/1375) tarafından kaleme alınan Şerh'in Şehdî Koleksiyonu'ndaki nüshası 803 (140001) yılında istinsah edilmiştir (Jahić, 1999, s. 401). Müstensihin adı 'Abdülcebbâr b. Gâzî'dir. Önceki sahiplerinden birinin adı Muhammed Amîn, bir diğerinin de Ahmed olarak kayda geçirilmiştir.

Muğni'l-lebîb 'an kütübi'l-e 'ârîb'in şerhi: Medreselerde nahiv sahasında okutulan önemli eserlerden biri İbn Hişâm'ın (ö. 761/1360) Muğni'l-lebîb 'an kütübi'l-e 'ârîb adlı eserdir. Bunun üzerine eş-Şumunnî (ö. 872/1468) tarafindan kaleme alınmış şerh el-Munsif min lelâm 'alâ Muğni'l-lebîb 'an kütübi'l-e 'ârîb başlığını taşır. Şehdî Koleksiyonu'ndaki nüsha 331 varak olup 10 Cemaziye'lahir 1107 (16 Ocak 1696) tarihinde istinsah edilmiştir (Jahić, 1999, s. 78).

el-Mukaddime el-âcurrûmiyye'nin şerhleri: İbn Âcurrûm'un (ö. 1323) nahiv sahasındaki meşhur eseri el-Mukaddime el-âcurrûmiyye üzerine kaleme alınmış 60 civarında şerhin en tanınmış ikisi Şehdî Koleksiyonu'na katılmıştır. ${ }^{26}$ Bunlardan biri, Ebû Zeyd 'Abdurrahmân b. 'Alî el-Mekûdî'nin (ö. 807/140405) kaleme aldığı Şerhü'l-âcurrûmiyye'dir (Jahić, 1999, s. 96). Kitabın 59b-60a varaklarında dil konusunda birkaç notla bazı gramer terimleri, 57b-59b'de ise bir cenaze duası kayda geçirilmiştir. Eser hakkında başka bilgiye ulaşılamamıştır.

Diğeri Hâlid b. 'Abdullâh el-Ezherî'nin (ö. 905/1499) yazdığı Şerhü'lâcurrûmiyye'dir (Jahić, 1999, s. 96). Sayfa kenarlarında okur notları bulunur. İlk sayfasında bazı hadisler ve Halife Ömer'e nisbet edilen Arapça metnin önemine dair sözler yazılı bulunur. Gene ilk sayfasında yer alan nottan ve mühürden kitabın belli olmayan dönemde İbrâhîm b. el-Hâc Mustafâ adında bir kadının mülkiyetinde bulunduğu görülür. Kendisini Hicâzî b. Mensûr b. Âlî olarak tanıtan kimse 1062 (1651-52)de istinsahını tamamlamıştır.

el-Mukaddimetü'l-ezheriyye fî 'ilmi'l- 'arabiyye'nin şerhi: Yukarıda adı geçen Hâlid b. 'Abdullâh el-Ezherî, el-Mukaddimetü'l-ezheriyye fì 'ilmi'l'arabiyye adlı kendi eseri üzerine bir de şerh yazmış; bu şerhin bir nüshası Şehdî Koleksiyonu'na alınmıştır (Jahić, 1999, s. 403). İstinsahını 923 (1517) yılında tamamlayan Mehmed Bahreddin b. Ahmad el-Me'arrî, müellifin söz konusu eseri 17 Zi'l-hicce 902 (16 Ağustos 1497) tarihinde bitirdiğini bir notta belirtmiştir. Kitabın başındaki bir kayıttan (1a) önceki sahiplerinden birinin 
adını Mustafâ b. Alî, daha sonraki bir başka kayıttan (40b) ise bir okurunun adını Muhammed el-Ezherî olarak okumak mümkündür.

İzhârü'l-esrâr'ın şerhi: İzhârü'l-esrâr, Mehmet Efendi Birgivî'nin elAvâmilüll-mi'e (el-Avâmilü'l-cedîde) adlı kendi eserini detaylı şekilde açıklamak amacıyla kaleme aldığ 1 bir eserdir (Hazer, 2002, s. 289). Eserin Hüseyin b. Ahmed Zeynî-zâde el-Bursevî (ö. 1168/1754-55) tarafindan Hall-ı esrârü'l-ahyâr 'alâ i'râb izhâri'l-esrâr adı altında yazılan şerhi Şehdî Koleksiyonu'nda yer almaktadır; söz konusu nüsha 1169 (1755-56) yılında çoğaltılmıştır (Jahić, 1999, s. 436).

\section{Belâgat İlmine Ait Kitaplar}

Telhîsü'l-miftâh ve şerhleri: Bilindiği gibi, Telhîsü'l-miftâh, Sekkâkî'nin (ö. 626/1229) Miftâhu'l- 'ulûm meşhur eserinin belâgata dair olan üçüncü bölümünün el-Kazvînî (ö. 739/1338) tarafindan yapılan muhtasarıdır. Telhîsü'lmiftâh'ın Şehdî Koleksiyonu'ndaki nüshasının Mustafâ b. Mahmûd el-Kâdî Hürremzâde tarafindan 26 Cemâziye'l-âhir 963 (7 Nisan 1556) tarihinde istinsah edildiğini müstensih kendi mühürüyle bildirmiştir (Popara \& Fajić, 2000, s. 13). Eldeki nüshanın 1158 (3 Subat 1745-23 Ocak 1746) yılında Şehdî Osmân Efendi'nin mülkiyetine geçtiği şahsî mühründen anlaşılmaktadır.

Yukarıda belirttiğimiz gibi Telhîsül'-miftâh'ı 1056 (1646-47)'da istinsah

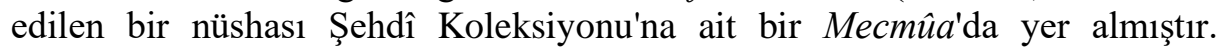
Sayfalarında görülen mühürden Mecmûa'nın 1173 (1759-60) yılında Şehdî Osmân Efendi'nin mülkiyetine geçtiği anlaşılmaktadır (Popara \& Fajić, 2000, s. 18).

Kazvînî'nin Telhîsü'l-miftâh'ı üzerine yazılmış şerhlerden, Taftâzânî'nin kaleme aldığ1 el-Mutavvel-şerh-i Telhîsül-miftâh çok okunan bir kitap olmuştur. Söz konusu şerhin Şehdî Koleksiyonu'ndaki nüshas1 895'in zu'l-hicce ayında (Ekim-Kasım 1490) istinsah edilmiştir (Popara \& Fajić, 2000, s. 59).

Taftâzânî'nin, el-Mutavvel'in daha kısa bir versiyonu olarak kaleme aldığ el-Muhtasar-şerh-i telhîsü'l-miftâh başlığıyla bilinen eserin Şehdî Koleksiyonu'ndaki nüshası 'Alî b. Halîl el-Karahisarî tarafından 1056-57 (1646-47) y1lında istinsah edilmiştir (Popara \& Fajić, 2000, s. 85).

Taftâzânî'nin el-Mutavvel'i üzerine yazılan Hâşiye el-Cürcânî 'alâ elMutavvel ise 'Alî b. Muhammed b. 'Alî Cürcânî'nin eseridir. Şehdî Koleksiyonu'ndaki nüshasının istinsahı 850 yılının Muharrem ayında (MartNisan 1446) tamamlanmıştır (Popara \& Fajić, 2000, s. 159). Müstensih kendi ismini yazmamış, bunun yerine şu Arapça beyti kayda geçirmiştir:

El-hatt yebkâ zamânen fî'l-kitâb / Ve sâhibü'l-hatti remîm (?) fítt-turâb. 
'Alî b. Muhammed b. 'Alî Cürcânî, Sekkâkî'nin Miftâhu'l- 'ulûm eserinin üçüncü bölümü üzerine de bir şerh yazmıştır. el-Misbâh-şerhü'l-Miftâh isimli bu eseri 803 yılı Şevvâl ayında (Mayıs-Haziran 1401) Semerkand'da tamamladığını kendisi belirtmiştir (Popara \& Fajić, 2000, s. 152). Daha sonra da bu şerh üzerine bir de haşiye kaleme almıştır. Hâsşiye 'alâ el-Miftâh li-Seyyîd eş-Şerîf el-Cürcânînin Şehdî Koleksiyonu'ndaki nüshası 72 varaktır. İstinsahına dair bilgi yoktur; ancak kâğıt, mürekkep ve yazısı 15. yüzyılda çoğaltıldığına işaret etmektedir. Kitaptaki mühürden 1173'ten (1759-60) itibaren Osmân Şehdî'nin mülkiyetinde bulunduğu görülür. Bundan önceki yıllarda Muhammed Hâşim adlı kimseye ait olduğu bir kayıttan anlaşılmaktadır.

\section{Değerlendirme}

\section{Kitaplara dair bilgiler}

Şehdî Osman Efendi Kütüphanesi'ne daha kuruluş devrinde konulan sarf, nahiv, belâgat ilim dallarına ait kitapların önemli kısmı Osmanlı medreselerinde Arapça eğitiminde okutulan ders kitaplarıdır. İlâhiyat ve İslâm hukuk dilinin Arapça olması medreselerde Arapça dil eğitimini zorunlu kılmıştır. Osmanlı coğrafyasında Arapça konuşulmayan bölgelerde medrese öğretiminin çeşitli seviyelerinde Arapça okutulmuştur. ${ }^{27}$

Eğitim kurumlarına bağlı kurulan kütüphanelerde medrese öğrencilerinin ulûmü'l-'aliye (yüksek ilimler) öğrenimini sağlayabilmek üzere ilk sırada ilâhiyat ve hukuk konulu eserler bulundurulmuştur; ancak öğrencilerin ilgili kitapları anlayabilmeleri ve yararlanabilmeleri için öncelikle Arap diline yatkınlık kazandırabilecek kitaplara yer verilmesi gerekiyordu. Öyle ki İstanbul'da II. Mehmed (Fatih, salt. 1451-1481) Külliyesi ile Edirne'de II. Bâyezid (salt. 1481-1512) Külliyesi'nde kurulan kütüphanelere konulan eserlerin önemli bir kısmı Arapça ders kitapları olmuştur (Erünsal, 2015, s. 397).

Osmanlı kütüphanelerinde Arapça ders kitaplarının bulunmasının ihtiyaç paralelinde gelişen bir gelenek olduğu söylenebilir. Ancak bir eğitim müessesine bağlı olmadan müstakil olarak kurulan Şehdî Osman Efendi Kütüphanesi'nde Arapça dilbilgisi kitaplarının bulundurulması, öncelikle koleksiyondan medrese öğrencilerinin de istifade edebilmelerinin düşünüldüğü akla getirir.

Diğer yandan, Arapça eğitimine dair kitaplar özel koleksiyonlarda da bulundurulmuştur. Şehdî Osmân Efendi'nin kütüphanesine kuruluş devrinde konulan Rûhu'ş-şurûh, el-Vâfiye fì şerhi'l-Kâfiye, el-Mukaddime elâcurrûmiyye şerhi, Muğni'l-lebîb 'an kütübi'l-e 'ârîb şerhi, el-Mutavvel-şerh-i Telhîsüll-miftâh gibi Arapça kitaplarından bazıları, bu koleksiyona girmeden önce kendilerini kad1, müderris ya da vaiz olarak tanıtan kimselerin 
mülkiyetinde bulunmuşlard. Bunlardan el-Mutavvel-şerh-i Telhîsüll-miftâh ve Telhîsü'l-miftâh ile Hâşiye 'alâ el-miftâh li Seyyîd eş-Şerîf el-Cürcânî adlı kitapları, sayfalarındaki 1158 (1745-46) tarihli mühürden anlaşıldığı gibi, Şehdî Osmân Efendi önce özel koleksiyonunda bulundurmuş, daha sonra kendisinin kurduğu kütüphaneye koymuştur.

18. yüzyılda yaygın bir şekilde ortaya çıkan kamuya açık müstakil kütüphanelerde de Arapçanın öğrenimini kolaylaştıracak ve geliştirecek kitaplara yer verilmiştir. Bu yeni tür kütüphaneler, literatürde işaret edildiği gibi, işleyiş bakımından diğer kütüphanelerden pek farklı değildi (Erünsal, 2015, s. 160). Arapça eğitimine dair kitapların koleksiyonlarına dahil edilmesi, eğitim müesseseleri mensuplarının da istifade edebilmelerinin öngörülmesinden ötürüdür. Aynı zamanda Osmanlı kültüründe "kitap koleksiyonu" oluşturmanın bazı vazgeçilmez unsurları bulunuyordu ve titizlikle geleneğin sürdürülmesi amaçlanıyordu.

Karşılaştırma için Saraybosna'nın 18. yüzyıl kitap koleksiyoncularının Arapça dil bilgisine dair kitaplarını hatırlamak yararlı olabilir. Örneğin, müderris Kantamirî Abdullâh Efendi'nin özel koleksiyonunu oluşturan 170 cilt arasinda el-İzâh fíl'-me 'ânî ve'l-beyân, Tuhfe-i Şâfiye fì șerh-i Kâfiye, Telhîsü'lmiftâh, Temhîsü'l-telhîs, Hâşiye 'ale'l-muhtasari'l-me 'ânî gibi 20'ye yakın Arapça ilmine ait kitap vardı (Fajić, 1987, s. 18-34.). Gene 18. yüzyılda Saraybosna'da yaşamış Velîhocaoğlu Mehmed Râzî Efendi'nin (ö. 1200/178586) özel kitap koleksiyonunda 160 eserden 17'si dil bilgisi alanına girer. Bunlardan bazıları Şâfiye, Şerh-i Kâfiye, Mugnî-i lebîb, Şerh-i Mugnî-i lebîb, Mirkatü'l-edeb, Mutavvel, Vankulı lugatı'dır (Mujezinović, 1987, s. 75-6).

Şehdî Osmân Efendi, Saraybosna'da kurduğu müstakil kütüphaneye Arapça dilbilgisi kitapları koyarak geleneği sürdürmüş̧ür. Kütüphanenin hizmete açıldığı dönemde Saraybosna'da ve Bosna bölgesinde iki yüzyıldan beri medrese eğitimi veriliyordu. ${ }^{28}$ Osmanlı medreselerinde Arapça öğretiminin geleneksel bir usulü vardı. Dolayısıyla Bosna bölgesinde kullanılan Arapça ders kitapları diğer bölgelerde kullanılanlardan farklı değildi ve çoğu bilinegelen eserler idi.

17. yüzyılın ikinci yarısında Saraybosna'da yaşamış ve hayatının bir döneminde Gazi Hüsrev Bey Medresesi'nde muîd görevini yapmış Şuglî Osmân Efendi'nin (ö. 1127/1715) el-Emsile el-muhtelife risalesi ile Cürcânî'nin Avâmilü'l-mie kitabı üzerine birer Türkçe şerh yazdığını, bu çalışmalarının muhtelif yerlerinde Şâfiye, Kâfiye, Mollâ Câmî gibi Arapça öğretiminde kullanılmış gramer kitaplarını zikrettiğini söylemekle yetinelim. ${ }^{29}$ Nitekim, çoğu zaman ilmiye kariyerinde ilerlemeyi sağlamak amaciyla şerh kaleme alan bir kişinin işlenecek konulara kaynaklık eden kitapları iyice tanıyıp incelemesi gerekiyordu (Hazer, 2002, s. 286). Şuglî Osmân Efendi örneği, Bosna 
bölgesinin kitap ve düşünce dolaşımı bakımından Osmanlı kültürüyle bütünleşmiş olduğunu göstermektedir.

Arapça dil eğitiminde geleneksel usule bağlı kalmalarıyla beraber Osmanlı âlimleri dil bilgisi alanında uzmanlıklarını şerh ve haşiyeler kaleme almakla ortaya koymaya çalışmışlardır. Bu çalışmaların neticesinde ortaya çıkan yeni kitaplar medrese ders programlarında yer alıp almamalarına bakılmadan kütüphane koleksiyonlarına alınıyorlardı. Diğer deyişle, kütüphane koleksiyonları ders kitaplarıyla sınırlı değildiler. Belki de bu tür kitapların kütüphane kurucusunun zevk ve tercihlerini daha çok yansıttıkları söylenebilir.

Şehdî Osmân Efendi'nin koleksiyonunda medreselerde kullanıma girmemiş kitapların bulunduğu da görülür. Örneğin Birgivî Mehmed Efendi tarafından kaleme alınmış 'Avâmilü'l-mie ve İzhârü'l-esrâr adlı Arapça grameriyle ilgili kitaplar Tanzimat'a kadar medreselerde ders programına alınmadıkları hâlde Şehdî Osman Efendi'nin kütüphanesinde yer almaktadır (Hazer, 2002, s. 284). Üstelik Hüseyin b. Ahmed Zeynîzâde el-Bursevî'nin İzhârü'l-esrâr üzerine yaptığı şerh de koleksiyonda yer almıştı. Yine Birgivî Mehmed Efendi'nin Imtihânü'l-ezkiyâ adında nahivle ilgili bir başka kitabını da Şehdî Koleksiyonu'nda buluyoruz.

Bundan daha çok dikkate değer bir husus, bu koleksiyonda Hâş̧iye 'alâ Imtihâni'l-ezkiyâ adlı bir kitabın bulunmasıdır ki 306 varaktan oluşan bu eserin sadece Şehdî Koleksiyonu'ndaki nüshası bilinmektedir. Eldeki nüshaya göre, yukarıdaki listede belirttiğimiz gibi, eserin müellifi Muhammed el-Kurdî idi (1b). Bu kişinin, kaynaklarda adına rastlanan Muhammed el-Kurdî es-Saharânî Munlâ-zâde (ö. 1070/1659-60) olabileceği ileri sürülmüştür, ancak yazma kataloglarında ve diğer kaynaklarda el-Kurdî'nin böyle bir haşiye yazdığı kaydedilmemiştir (Jahić, 1999, s. 399).

Neredeyse tamamı Arapça olan kitaplar arasında Türkçe kaleme alınmış iki eser vardır. Biri Ahmed Sûdî Bosnevî'nin Şerhü'l-Kâfiye adlı eseridir. Diğeri 18. yüzyılda Dâvûd el-Karsî (ö. 1169/1756) tarafından kaleme alınmış elEmsile el-muhtelife üzerine bir şerhtir. ${ }^{30}$ el-Emsile el-muhtelife risalesi üzerine yüzyıllar boyunca Arapça ve Türkçe yazılan şerhler arasında Osmanlı medreselerinde en çok okunanlar arasında Dâvûd el-Karsî'nin şerhi olmuştur. ${ }^{31}$ $\mathrm{Bu}$ Türkçe şerhin nüshası, yukarıdaki listede işaret ettiğimiz gibi, Şehdî Koleksiyonu'na ait bir Mecmûa'da yer alır.

\section{İstinsaha dair bilgiler}

Bir kitap kendi içeriğiyle kaleme alındığı ve kullanımda bulunduğu dönem(ler)in bilim-kültür hayatını, insan düşünce ve zihniyetini yansıtır. İçeriğinin yanısıra her bir eser, sayfalarında rastlanan exlibris ve derkenar kayıtlarında da önem taşıyan bilgiler barındırır. 
Listemizdeki kitapların müstensihleri ne yazık ki kendileri hakkında isimleri dışında bilgi bırakmamışlardır. Bu sebeple kimler oldukları, ne iş yaptıkları konularında kesin bir şey söylememiz mümkün olmamaktadır. Hâşiye el-Cürcânî 'alâ el-Mutavvel başlıklı yazmada müstensih kendi adını zikretmemiş, bunun yerine ruhunun hâlini belirten şu Arapça beyiti yazmıştır:

el-Hatt yebkâ zamânen fí'l-kitâb / Ve sâhibü'l-hatti remîm (?) fî't-turâb.

Yazı uzun zaman boyunca kitapta kalır / Yazı yazan ise toz toprak olur.

İçeriğine bakıldığında, bu beyit müstensihin bir dua için istirhamı olarak kabul edilebilir. ${ }^{32}$ Așağıda göstereceğimiz gibi, 850 (1446)'de istinsah edilmiş olan bu yazma Şehdî Koleksiyonu'ndaki en eski eserlerdendir. Osmanlı kültüründe kitap üretimi belli merkezlerde toplanmadığından okuması yazması olan herkes istinsah yapabilirdi. ${ }^{33}$ Yukarıdaki listede adı bulunan müstensihler arasında kuşkusuz kendisi sahip olmak üzere kitabı çoğaltanlar da bulunuyordu.

İstinsah yeri belli olan nüshalar kitap üretim yerinin ilk sirada medreseler olduğu görüşünü güçlendirmektedir. el-Vâfiye fî şerhi'l-Kâfiye'nin iki nüshasından biri 870 (1465-66)'de İstanbul'da Mollâ Zeyrek Medresesi'nde, Zav'u'l-Misbâh muhtasar el-Miftâh adlı eser 1027 (1618)'de Bayram Gâzî Medresesi'nde kopya edilmiştir. Taftâzânî'nin el-Muhtasar-şerh-i Telhîsü'lmiftâh başlığındaki eserinin istansahı, müstensihin sözlerine göre, sekiz ayda (Zi'l-kade 1056-Receb 1057/Aralık 1646-Temmuz 1647) tamamlanmıştır. Aynı ciltte bulunan Telhîsü'l-miftâh'1n istinsah yeri Beşiktaş'ta Sinan Paşa Medresesi olduğuna göre, Risâle-i 'avnü'l-Vâfiye fì şerh-i kitâbi'l-Kâfiye'nin de aynı yerde çoğaltıldığını tahmin etmemiz mümkündür. Müstensihler ise, çoğu zaman ya o medreselerin öğrencileri ya da görevlileriydiler. Literatürde söylendiği gibi, dil ve gramer kitaplarını istinsah edebilmeleri için öğrencilere kolaylık gösteren müesseseler vardı (Erünsal, 2015, s. 465).

Öte yandan Mollâ Câmînin istinsahını 1053 (1643-44) yılında tamamlayan Şerîf Muhammed bir müesseseye bağlı olduğunu yazmamış, sadece "Nurci köyü" şeklinde okuyabileceğimiz bir yeri belirtmiştir. Bunun gibi örnekler istinsah işinin sadece belli merkezlerde ve müesseselerde değil, farklı yerlerde de yapıldığını kanıtlar.

Şehdî Koleksiyonu'na ait Arapça grameriyle ilgili el yazmalarının büyük çoğunluğu - esas nüshalar gibi şerhler de - 16. yüzyıldan önce kaleme alınmış eserlerdir. İstinsah tarihi belli olanlardan 13'ü 17. yüzyıla, üçü 18. yüzyıla aittir. Geri kalan 12 yazmanın beşi 16. yüzyılda, yedisi 15. yüzyılda istinsah edilmiştir.

İstinsah tarihi en eski olan eser 803 (1400-01) yılında çoğaltılan İbn Nukrekâr'ın Şerh-i Lübbi'l-elbâb fí 'ilmi'l-i 'râb adlı şerhidir. Müstensihin ve iki eski sahibinin isimleri bilindiği hâlde, yazmanın nerede çoğaltıldığı ve 
okunduğu bilgisi bulunmamaktadır. 850 (1446) yılına tarihlenen Hâşiye elCürcânî 'alâ el-Mutavvel ile 857 (1453) y1lında istinsah edilmiş olan el-Vâfiye fì şerhi'l-Kâfiye için de bu tür bilgiler eksiktir. Ama İstanbul'un fethinden sonra, 870 (1465-66)'de istinsah edilmiş el-Vâfiye'nin Şehdî koleksiyonundaki bir başka nüshasında İstanbul'da Mollâ Zeyrek Medresesi'nde kopyalanmış olduğu belirtilmiştir. İstinsah yeri belli olmayan, 895 (1490) yılında tamamlanmış Taftâzânî'nin el-Mutavvel-şerh-i Telhîsü'l-miftâh adlı eserinin, önceleri Şeyh Osmân adında Ayasofya vaizi'nin elinde, daha sonra Şehdî Osmân'ın mülkiyetinde bulunduğu ve 1173'te (1759-60) Şehdî Osmân Efendi tarafindan kütüphanesine koyulduğu ilk sayfadaki (1a) notlardan anlaşılmaktadır.

İstinsah tarihleri, esas eserin kaleme alındığı tarihe yakınlığı bakımından değerlendirildiğinde Şerh-i Lübbü'l-elbâb fì 'ilmi'l-i 'râb'ı bir kez daha anmak gerekir. Müellifin ölüm y1lı 776 (1375), istinsah y1lı ise 803 (1400-01) olduğuna göre, eser kaleme alınmasına nisbeten yakın bir zaman içerisinde kopya edilmiştir. Benzer bir durum Hâssiye el-Cürcânî 'alâ el-Mutavvel'in nüshasinda görülür. Söz konusu nüsha, müellifin ölümünden 33 yıl sonra, 850 (1446)'de istinsah edilmiştir. Sayfalarındaki bir kayıttan 985 (1577)'de Hüseyin b. 'Abdulkerîm'in elinde bulunduğu anlaşılan Mollâ Câmî şerhi'nin eldeki nüshası da müellifi el-İsferâyînî'nin ölüm yılına (944/1537-38) yakın bir tarihte tamamlanmıştır.

Daha sonraki yüzyıllara ait yazmalar arasında esas eserin kaleme alındığı tarihe yakın bir zamanda çoğaltılımış olanlar da bulunmaktadır. Örneğin, Hall-l esrârü'l-ahyâr 'alâ İzhâri'l-esrâr'ın Şehdî Koleksiyonu'ndaki nüsha, müellifi Hüseyin b. Ahmed el-Bursevî'nin 1168 (1754-55)'de ölümünden bir y1l sonra 1169 (1755-56)'de kopya edilmiştir. Müstensihin adı ve istinsah yeri belli olmayan bu nüsha, GHBK'nde bugün mevcut olan Hall-ı esrârü'l-ahyâr 'alâ İzhâri'l-esrâr'ın 12 nüshası arasında en eski tarihli iki nüshadan biridir. ${ }^{34}$ Mevcut 12 nüshanın ikisinde müellifin bu eseri 15 Cemâziye'l-âhir 1152 (19 Eylül 1739) Perşembe günü ikindi namazından sonra tamamladığını belirten kayıt bulunur (Jahić, 1999, s. 439). Bu bilgiye göre Şehdî Koleksiyonu'na ait olan nüsha, eserin yazımından 16-17 yıl sonra çoğaltılmıştır.

Müellifi kesin olarak bilinmeyen bir eser, R̂̂hu'ş-şurûh, ölüm y1l 1061 (1650-51) olan et-Tirevî'ye atfedildiği yukarıda söyledik. Bu doğru ise, 1082 (1671-72)'de istinsah edilmiş olan Şehdî Koleksiyonu'ndaki nüshanın eserin yazılmasından 20 yıl sonra kopyalanmış olduğu anlaşılır.

\section{Derkenar kullanıma dair bilgiler}

$\mathrm{Bu}$ yazının konusu olan el yazmalarının yaklaşık olarak yarısında muhtelif okurlar tarafından sayfa kenarlarına, ön ve son kapaklarda düşülen notlara rastlanmaktadır. $\mathrm{Bu}$ notların bir kısmı kitabın içeriğiyle ilgilidir; (bazı) okurların metinden "diyalog" kurarak istifade ettiklerine tanıklık etmekte ve söz 
konusu kitabın ilim hayatında aktif bir rolü olduğunu göstermektedirler. Arapça eserlerde notlar Arapçadır ve genel olarak okurun zihinsel gayret sonucunda kendisi için yaptığı hatırlatma ya da kısa açıklama niteliğindedir, konu ile ilgili yeteneklerini yansitmaktadır.

El yazmalarının ön ve arka kapaklarında Türkçe, Farsça veya Arapça şiirlere, cenaze duası gibi çeşitli kayıtlara rastlanır. Bu tür kayıtlar, kitabı kullanan kimsenin o sırada yaşadıklarının yansımasıdür kuşkusuz. Gerektiğinde başvurabilmek için, güvenli bir yerde saklanmak üzere kitap sahibi/okur duygularını, dünya görüşünü kaydetmiş olabilir. Kitap sahibi ya da okur kitap sayfalarına kendisi için bazı notlar yazmış olabileceği gibi, kendisinden sonra kitabı kullanacak kişileri düşünerek de notlar almış olabilir. Olası ki bildiği bir duayı, beğendiği belki de bir ilham anında düzdüğü beyitleri başkalarıyla paylaşmak istemiştir. Dolayısıyla, bu tür kayıtlar da bilgi alışverişi olarak değerlendirilebilir.

Medrese, cami, külliye gibi bir müesseseye bağl1 kurulan kütüphanelerin okurlara daha çok ödünç verme yoluyla hizmet ettikleri (Erünsal, 2015, s. 436) 17. yüzyıldan itibaren kütüphanelerin çalışma tarzı yeniden düzenlenerek kitapların kütüphane içinde okunması ve dışarı çıkarılmaması gibi şartların konulmasının yaygınlaştı̆̆ bilinir (Erünsal, 2015, s. 440-43). Şehdî Osmân Efendi'nin vakfiyesi elimizde bulunmadığından, benzer şartların koyulup koyulmadığı belli değildir.

Öte yandan, Şehdî Kütüphanesi'nden kitapları dışarı çıkarmanın mümkün olduğuna dair bir işaret dikkat çeker. Yukarıda el-Vâfiye fì şerhi'l-Kâfiye adlı eserin iki nüshasının koleksiyonda bulunduğunu söylemiş̧tik. Bu iki nüshadan birinin kütüphaneden çıkarılıp bir süre dışarıda kaldığı tespit edebiliyoruz: Muhammed Şevkî Efendi Kurt'a (ö. 1963) ait olan yazma eser koleksiyonu, yaklaşı 50 sene önce oğlu Dr. Aliya Kemal Bey (ö. 1984) tarafından GHBK'ne bağışlanmıştır. ${ }^{35}$ Bağış̧lanan kitap koleksiyonunda 870 (1465-66)'de İstanbul'da Mollâ Zeyrek Medresesi'nde Halîl b. Yûsuf tarafından istinsah edilmiş bir elVâfiye fì şerhi'l-Kâfiye'nin nüshası bulunmaktadır. Şehdî Kütüphanesi'nin 1173 (1759-1760) tarihli mührünü taşıyan bu kitabın Muhammed Şevkî Efendi'ye hangi yol(lar)dan ulaştığını, Şehdî Kütüphanesi dışında ne kadar süre kaldığını bilemeyiz; ancak esasen ait olduğu koleksiyona geri dönmesi şans eseri olmalıdır.

O dönemde Saraybosna'da -İmparatorluğun başka yerlerinde olduğu gibikütüphaneden kitap ödünç alarak yararlanmanın mümkün olduğunu Mollâ Mustafâ Başeski'nin Mecmûa'sından öğrenmekteyiz. Yazar, Saraybosna âlimlerinden Hafiz Mollâ Mahmûd (ö. 1239/1823-24) hakkında şunları söylemişti: Ve İslâmbol'da bir parça meks edüp bu tarafa geldi. Ve geldikde 'âriyyeten kitâbları alup 'akl-ı evvel, zekî, zihni pâk oldıgından hocasız 'ilm kendüye feth oldı, bi'llâhi zann ederim (Filan, 2011, s. 146). Mollâ Mahmûd'un 
hâfiz-ı kütübhâne vazifesinde bulunduğuna göre (Filan, 2011, s. 139) görev yaptığı kütüphanenin kitaplarından yararlanm olmalı. Literatürümüzde işaret edildiği gibi, kendisi bu görevi Şehdî Kütüphanesinde yapmıștır. ${ }^{36} \mathrm{Her}$ hâlukârda hafız-1 kütüblük ulemâ sınıfına ait bir meslek olduğuna göre (Erünsal, 2015, s. 336), Mollâ Mahmûd'un bu görev için aranan vasıflara sahip bir kişi olduğunu düşünmemiz mümkün. ${ }^{37}$

\section{Ana koleksiyonun zenginleştirilmesine dair bilgiler}

Şehdî Osmân Efendi tarafindan kurulan kütüphanenin Saraybosna'nın ilmîkülürel hayatında önemli bir yer kazandığına işaret eden göstergelerden biri kütüphaneye sürekli kitap bağışlarının yapılmış olmasıdır. Bu yazının başında Saraybosna kadısına ait Şer'iye Siciller'ine göre 19. yüzyılda gerçekleştirilen iki toplu bağış zikredilmiştir. Bu bağışlar hakkında bilgi sınırlıdır ve ileride konuyu aydınlatacak yeni bilgilere ulaşılabileceğini umarak, burada kesin olarak bilinen bağışlara bakacağız.

Seyyid Süleymân Râ'if Efendi adında bir kişi Şehdî Kütüphanesi'ne Mugnî el-edeb - Muhtasar an-Nisfi'l-evvel min Mugni'l-lebîb başlığını taşıyan bir el yazması bağışlamıştır (Jahić, 1999, 71). Adından anlaşıldığı gibi bu eser İbn Hişâm'ın Mugni'l-lebîb 'an-kutubi'l-e 'arib eseri üzerine bir şerhtir; ancak kimin tarafindan, ne zaman ve nerede kaleme alındığına dair bilgi bulunmamaktadır. Eldeki nüshanın 1126'nın Safer ayında (Şubat-Mart 1714) istinsah edildiği, sayfalarına adlarını kaydetmiş üç kişinin mülkiyetinde bulunmuş olduğu bilinmektedir. Eserin Seyyid Süleymân Râ'if Efendi'den önceki sahiplerinden biri kendisi hakkında bilgiye ulaşılamayan el-Hâc 'Ubeydullâh Zühdî idi. İkinci sahibi Saraybosna Gazi Hüsrev Bey Medresesi müderrislerinden el-Hâc Ahmed, üçüncü bir sahibi ise, aynı medresenin müderrisi Muhammed b. el-Hâc Ahmed idi (Jahić, 1999, s. 72). Bu iki müderrisin adlarına bakarak baba-oğul oldukları tahmin edilebilir.

Gazi Hüsrev Bey Medresesi'nde müderris görevine 1178 (1765) y1lında Bosnali âlimlerinden Dupniçeli Ahmed Efendi getirilmiştir (Kreševljaković, 1932, s. 149). Kendisi hakkında Mollâ Mustafâ Başeski "Hüsrev Beg Medresesi'nde müderris, ve bu dahi her 'ilmden bilmem demezdi, illâ nahvile ve mantıkla taslardı"ş̧eklinde bir kayıt düşmüştür (Filan, 2011, s. 145). ${ }^{38} \mathrm{Bu}$ kayıttan anlaşıldığ 1 gibi, Ahmed Efendi nahiv ilmine ilgi göstermiştir. 1227 (1812) yılında ölümünden sonra oğlu Muhammed Efendi aynı medresede müderris olmuştur. Muhammed Efendi, Saraybosna'nın 19. yüzyıl ilim hayatında önemli kişilerden biri olarak bilinir; literatürde belirtildiği gibi, ölümünden uzun seneler sonra dahi Bosna halkı arasında büyük âlim olarak anılmıştı (Kreševljaković, 1932, s. 150). Bütün bunlara göre, Seyyid Süleymân Râ'if Efendi'nin Şehdî Kütüphanesi'ne bağışladığı Muğni'l-edeb-Muhtasar anNisfi'l-evvel min Muğni'l-lebîb baba-oğul bu iki müderrisin elinde bulunmuş 
olabilir. Öte yandan, bu eserin başka kaynaklarda zikredilmemiş olması, müellifinin de bu coğrafyadan bir kimse olabileceği ihtimalini düşündürür ancak bu ihtimal şimdilik sağlam bir dayanaktan yoksundur. Her hâlükârda Muğni'l-edeb-Muhtasar an-Nisfi'l-evvel min Muğni'l-eebîb adlı el yazmasının, ana koleksiyonun bağış yoluyla zenginleştirilmesi sayesinde sadece Şehdî Kütüphanesi'nde bulunan, başka nüshası bilinmeyen bir gramer kitabı olduğunu söylemek gerekir.

Saraybosna'nın Ali Paşa mahallesinde sakin 'Abdullâh b. Süleymân Odunc1-zâde Muvassilü't-tullâb ilâ kavâ 'idi'l-i 'râb adlı el yazmasını Şehdî Kütüphanesi'ne bağışlamıştır (Jahić, 1999, s. 127). İbn Hişâm'ın el-İ'râb 'an kavâ'idi'l-i 'râb adı altında bilinen eseri üzerine yazılmış bir şerhtir. Şerhin müellifi Hâlid b. 'Abdullâh el-Ezherî'dir. O zamana kadar Şehdî Koleksiyonu'nda İbn Hişâm'ın eseri bulunmadığı gibi, söz konusu şerh de mevcut değildi. ${ }^{39}$

Bunların yanısıra Gazi Hüsrev Bey Kütüphanesi Kataloğu'nda Şehdî Koleksiyonu'na ait oldukları belirtilen bazı el yazmalarının ne zaman ve kimden geldikleri ne yazık ki bilinmemektedir. Mesela içinde Merâhü'l-ervâh metni bulunan bir Mecmûa'nın (Jahić, 2000, s. 162-163) geldiği yer ve geliş tarihi belli değildir. Tespitimize göre ana koleksiyonda Merâhü'l-ervâh'ın nüshası bulunmamaktadır. ${ }^{40}$ Mecmûa'daki nüshanın sayfa kenarlarında, satırlar arasında ön ve son kapaklar içinde çok sayıda notlar bulunur. Notların hepsi kitabın içeriğiyle ilgilidir. Bundan nüshanın çok kullanıldığı anlaşılır. 995-99 (158791) yılları arasında istinsah edildiği düşünülmektedir (Jahić, 2000, s. 162); dolayısıyla çoğaltıldığı tarih Merâhü̈l-ervâh'ın medreselerde okutulmaya başladığı döneme rastlar. Kitabın başında adı kaydedilmiş olan Halîl b. Sâlih elBosnevî önceki sahiplerinden olabilir. Bundan nüshanın Şehdî Kütüphanesi'ne dahil edilmeden önce bir süre Bosna'da dolaşımda bulunduğu anlaşılmaktadır.

Şehdî Kütüphanesi'ne bağış olarak gelmiş iki Mecmûa'da müellifleri belli olmayan Türkçe kaleme alınmış Şerh-i el-Emsile el-muhtelife'nin nüshaları bir araya getirilmiştir (Jahić, 2000, s. 336 ve 349). Bunlardan birinin istinsahını Halîl El-Bosnevî adında bir kişi 1224 (1809-10) yılında yapmıştır. Nüshanın sonundaki boş sayfalarda Arap diliyle ilgili bazı Türkçe notlar bulunur. Bu tür kayıtlar, Arapçayı Türkçe üzerinden öğrenen öğrencilerin olduğuna işaret etmektedir. Ancak, bunun ne derecede yaygın bir yöntem olduğunu söylemek zordur. GHBK'nde büyük sayıda Emsile ile Avamilu'l-mie'nin Arapça şerhleri mevcuttur. Bu nüshaların da kullanımda bulundukları kuşkusuzdur. Şehdî

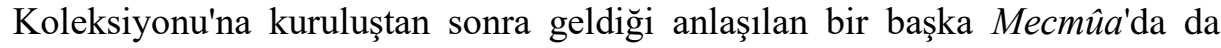
Emsile'nin Arapça kaleme alınmış bir şerhi yer alır. Ne yazik ki bu şerhe dair bilgi yoktur, müellifi, müstensihi, istinsah yeri ve tarihi bilinmemektedir. Ana koleksiyona dahil edilmiş Dâvûd El-Karsî'ninki ve sonraki yıllarda gelen bu iki nüsha ile Şehdî Koleksiyonu'nda Emsile şerhlerinin sayısı üçe çıkmıştır. 


\section{Sonuç}

Eldeki bilgilere göre Şehdî Osmân Efendi'nin 18. yüzyılda Saraybosna'da kurduğu müstakil kütüphanenin ana koleksiyonu yaklaşık olarak 180 ciltten oluşmaktadır. İlâhiyat ve İslâm hukuku alanlarından olan kitapların yanısıra bu çalışmada ele alınan Arapça dilbilgisi üzerine olanlar da dikkati çeken sayı ve niteliktedir.

İslâmî ilimler için gerekli olan Arapça eğitim müesseselerinde öğretiliyordu; Arapça dilbilgisi üzerine kitaplar kütüphane koleksiyonlarında bulunduruluyordu. Bu noktada Osmanlı kütüphaneleri ile Batı dünyasında Orta Çağ kütüphaneleri arasında bir paralellik görülmektedir. Koleksiyonlarının büyük kısmını Latince kaleme alınmış dinî ilimlere ait eserler oluşturan Orta Çağ kütüphanelerinde Latince gramerleri de yer almıştır (Pelc, 2002, 76). Dönemin okullarında ilâhiyat dışı Latince eserlerin de öğrencilere okutulduğu bilinmektedir. Böylelikle öğrencilerin Latin dilinde alıştırma yapabilmelerinin, ilâhiyat konusunda kitapları okumaları ve daha iyi anlamalarının mümkün olduğu derecede kolaylaştırılması amaçlanmıştır (Pelc, 2002, s. 76).

Osmanlı kültüründe eğitim müesseselerine bağlı kütüphanelerde olduğu gibi, müstakil olarak kurulanlarda da, özel koleksiyonlarda da Arapça dilbilgisi kitapları bulunmaktadır. $\mathrm{Bu}$ tür kitapların kitap koleksiyonlarının yapı taşlarından olduğu söylenebilir. Günümüzde Saraybosna'nın GHBK'nde korunan Şehdî Koleksiyonu'na ait Arapça dili üzerine el yazmalarına bakıldığında önemli bir kısmının Osmanlı medreselerinde Arapça öğretiminde okutulan ders kitapları olduğu görülür. Sarf, nahiv, belâgat olmak üzere Arapça öğretiminin gerçekleştirildiği her üç daldan kitaplara yer verildiği dikkatimizi çeken bir husustur. Nitekim, literatürde gösterildiği gibi, "müstakil kütüphanelerde koleksiyonların İslâmî ilimlerle ilgili kitapları dengeli bir şekilde ihtiva etmesine dikkat edilmiştir" (Erünsal, 2015, s. 399). Bu uygulamanın dilbilgisi kitapları için geçerli olduğu görülmektedir. Koleksiyonun bir başka özelliği, bir eserin birden fazla nüshasının dahil edilmemiş olmasıdır. Ana koleksiyonda yer alan 30'dan fazla gramer konulu kitap arasında sadece el-Vâfiye fì şerhi'l-Kâfiye, Hâşiye 'alâ şerh-i dîbâcetü'lMisbâh ve Şerh-i Elfiye-i İbn Mâlik başl1klı üç eserin ikişer nüshası bulunmuştur. Bunlardan Hâssiye 'alâ şerh-i dîbâcetü̈l-Misbâh'1n nüshaları iki ayrı mecmûada, Şerh-i Elfiye-i İbn Mâlik'in bir nüshası da bir diğer mecmûada yer alır.

Bazı eserler, kendileri koleksiyona alınmamış olsalar da, üzerlerine yazılmış şerh ve haşiyelerin Şehdi Kütüphanesi'nde yer bulduğu görülür. Bunların bazıları, esas eserlerle birlikte, medrese geleneğinde iyi bilinen, çok okutulan metinlerdir. Kuşkusuz bu tür kitapları istinsah yoluyla seri üretim 
çoğaltıldıklarından elde etmek de daha kolay olmuştur. Ancak ulaşılması daha kolay olduğu tahmin edebildiğimiz bu kitapların yanısıra koleksiyona alınanlar arasinda medreselerde okutulmayan kitaplar vardır. Böylece kaynaklarda anılmayan Hâş̧iye 'alâ İmtihâni'l-ezkiyâ adlı eser bugün sadece Şehdî Kütüphanesi'nin ana koleksiyonunda yer almış nüshasıyla bilinir.

Şehdi Kütüphanesi'nin kurulduğu bölgede ilim-kültür hayatında belli bir yere sahip olduğuna işaret eden hususlardan biri kuruluşundan sonraki yıllarda yerliler tarafından kitap bağışlarının yapılmış olmasıdır. Koleksiyondaki kitaplardan yararlanma imkanları hakkında bilgimiz sınırlı olduğu halde, ödünç kitap alınması mümkün olduğu sonucuna bizi götüren bir durum tespit edilmiştir. Bütün bunlara göre Şehdî Kütüphanesi'nin kuruluş amacına ulaştığ1 söylenebilir.

$\mathrm{Bu}$ çalışmanın başında ileri sürüldüğü gibi, bu müessesenin kurulduğu bölge için en önemli ayrıcalığı müstakil bir kütüphane olmasıdır. 17. yüzyılda başlatılan, bundan sonraki yüzyıllarda yaygınlaşan müstakil kütüphane kurma uygulaması Osmanlı kültürüne yeni bir hareket vermiştir. Şehdî Osmân Efendi'nin kütüphanesiyle Bosna bölgesinin Osmanlı kültürü ile bu anlamda da bütünleşmesi gerçekleştirilmiştir. Hacegân-1 dîvân ünvanına sahip bir devlet adamının bölgeye getirdiği bu yenilik, yukarıda söylendiği gibi, Kantamirî Abdullâh Efendi adında Bosnalı bir âlim kişinin 1774 yılında, müstakil bir kütüphane kurmasıyla devam etmiştir.

\section{Kaynakça}

Ahmed, Sh. and N. Filipović (2004). "The Sultan's Syllabus: A Curriculum for the Ottoman Imperial medreses prescribed in a fermān of Qanūn̄ Süleymān, dated 973 (1565)." Studia Islamica, (sy. 98-99, s. 183-218), Leiden: Brill.

Anameriç, H. (2006). "Osmanlılarda kütüphane kültürü ve bilimsel yaşama etkisi." OTAM Osmanlı Tarihi Araştırma ve Uygulama Merkezi Dergisi, (sy. 19, s. 53-78), Ankara: Osmanlı Tarihi Araştırma ve Uygulama Merkezi.

Arslan, A. T. (1995). "Ezherî, Hâlid b. ‘Abdullah”, Türkiye Diyanet Vakfi İslâm Ansiklopedisi, (XII, s. 64-65), İstanbul: Türkiye Diyanet Vakfı Yayınları.

Arslanoğlu, O. O. (2016). „Nasrullah Kadı ve Nasrullah Kadı camii etrafında kurulmuş medreseler". In A. R. Özkan (Ed.), III Uluslararası Şeyh Şa'bânı Velî sempozyumu - „Kastamonu'da ilmî hayat ve Kastamonu âlimleri “, (s. 249-263), Kastamonu: Kastamonu Üniversitesi İlahiyat Fakültesi.

Aynur, H. (2002). "Türkiye'de Türkçe yazma eserlerin kataloglanması üzerine bir değerlendirme 1989-2002." Journal of Turkish Studies / Türklük Bilgisi 
Araştırmaları, (vol. 26 (I), s. 37-52), Harward University Department of Near Eastern Languages and Civilisations.

Bejtić, A. (1981). „Jedno viđenje sarajevskih evlija i njihovih grobova kao kultnih mjesta“. Prilozi za orijentalnu filologiju (sy. 31, s. 111-129) Sarajevo: Orijentalni institut u Sarajevu.

Çögenli, M. S. (2006). „Mutarrizî“. Türkiye Diyanet Vakfı İslâm Ansiklopedisi, (XXXI, s. 375-377), İstanbul: Türkiye Diyanet Vakfı Yayınları.

Čar-Drnda, H. (1990). "Neki legati Osman-Šehdijine biblioteke." Anali Gazi Hüsrev-begove biblioteke (sy. 15-16, s. 243-252), Sarajevo: Gazi Hsurevbegova biblioteka.

Demir, U. (2010). "Şehdî Osman Efendi." Türkiye Diyanet Vakfi İslâm Ansiklopedisi, (XXXVIII, s. 427-428), İstanbul: Türkiye Diyanet Vakfı Yayınları.

Dobrača, K. (2000). "Gazi Hüsrev-begova biblioteka u Sarajevu." In E. Kujundžić (Ed.), Gazi Hüsrev-begova biblioteka: Pet stoljeća u misiji bošnjačke kulture, (s. 106-111), Sarajevo: Gazi Hüsrev-begova biblioteka \& El-Kalem.

Durmuş, İ. (1991). "El-“Avâmilü'l-Mie.” Türkiye Diyanet Vakfi İslâm Ansiklopedisi, (IV, s. 106-107), İstanbul: Türkiye Diyanet Vakfi Yayınları.

, (1995). “Emsile.” Türkiye Diyanet Vakfi İslâm Ansiklopedisi, (XI, s. 166-167), İstanbul: Türkiye Diyanet Vakfı Yayınları.

Dursun, H. (2002). "Osmanlı Medreselerinde Arapça Öğretimi ve Okutulan Ders Kitapları.” Gazi Üniversitesi Çorum İlahiyat Fakültesi Dergisi, (sy. I, s. 274-293), Çorum: Gazi Üniversitesi Çorum İlahiyat Fakültesi.

Erünsal, İ. E. (2015). Osmanlılarda Kütüphaneler ve Kütüphanecilik. İstanbul: Timaş.

Fajić, Z. (1987). "Biblioteka Abdulah-efendije Kantamirije." Anali Gazi Hüsrev-begove biblioteke, (sy. 13-14, s. 15-36), Sarajevo: Gazi Husrevbegova biblioteka.

, (1983). „Originali i prepisi vakufnama sačuvanih do danas.“ Anali Gazi Hüsrev-begove biblioteke (sy. 9-10, s. 25-28), Sarajevo: Gazi Husrevbegova biblioteka.

Fazlıoğlu, Ş. (2005). "Ta'lîm ile İrşâd arasında: Erzurumlu İbrahim Hakkı'nın medrese ders müfredatı." DÎVÂN İlmî Araştırmalar, (sy. 18, s. 115-173), İstanbul: Bilim ve Sanat Vakfi. 
Filan, K. (2011). (Trans.) XVIII. Yüzyıl Günlük Hayatına Dair Saraybosnalı Molla Mustafa'nin Mecmuası. Sarajevo: Connectum.

, (2017). O turskom jeziku u Bosni:Studija. Sarajevo: Connectum.

Frkin, V. (2012). “Knjižnica Franjevačkog samostana u Požegi.” Radovi Zavoda za znanstveni u umjetnički rad u Požegi, (sy. 1, s. 33-38), Požega: Zavod za zdravstveni i umjetnički rad.

İçimsoy, A. O. \& İ. E. Erünsal (2008). "The Legacy of the Ottoman Library in the Libraries of the Turkish Republic." Libri, (sy. 58, s. 47-57).

İpşirli, M. (2005). "Molla Zeyrek." Türkiye Diyanet Vakfı İslâm Ansiklopedisi, (XXX, s. 266-267), İstanbul: Türkiye Diyanet Vakfı Yayınları.

Jahić, M. (1999). (Ed.) Katalog arapskih, turskih, perzijskih $i$ bosanskih rukopisa. Svezak 6. London: “Al-Furqân” Fondacija za İslâmsko naslijeđe, Sarajevo: Rijaset Islamske zajednice u BiH.

, (2000). (Ed.) Katalog arapskih, turskih, perzijskih i bosanskih rukopisa. Svezak 8. London: “Al-Furqân” Fondacija za İslâmsko naslijeđe, Sarajevo: Rijaset Islamske zajednice u BiH.

Kasumović, I. (1999). Školstvo i obrazovanje u Bosanskom ejaletu za vrijeme osmanske uprave. Mostar: Islamski kulturni centar.

Kemura, S. F. (2000). "Kutubhana kod Careve džamije.” In E. Kujundžić (Ed.) Gazi Hüsrev-begova biblioteka: Pet stoljeća u misiji bošnjačke kulture, (s. 237-248). Sarajevo: Gazi Hüsrev-begova biblioteka \& El-Kalem.

Kilıç, H. (1999). "Ibn Âcurrûm.” Türkiye Diyanet Vakfi İslâm Ansiklopedisi, (XIX, s. 295-296), İstanbul: Türkiye Diyanet Vakfı Yayınları.

Kreševljaković, H. (1932). "Muderisi Hüsrev-begove medrese.” In Spomenica Gazi Hüsrev-begove četiristo-godišnjice, (s. 146-152), Sarajevo: Islamska dioničarska štamparija.

"Muhamed Šefket ef. Kurt (1879-1963), muftija u Banja Luci i Tuzli. Porodica Kurt iz Mostara.“ (2021). Retrieved from https://porodicakurt.com/muhamed-sefket-kurt/ (Erişim tarihi: 25/03/2021)

Mujezinović, M. (1974). Islamska epigrafika Bosne i Hercegovine. Knjiga I Sarajevo. Sarajevo: Veselin Masleša.

, (1987). "Biblioteka Mehmed-Razi Velihodžića šejha i muderisa Hüsrev-begova hanikaha u Sarajevu." Anali Gazi Hüsrev-begove biblioteke, (sy. 5-6, s. 65-82), Sarajevo: Gazi Husrev-begova biblioteka. 
Mujić, M. (1983). "Neke vakuf-name iz Bosne i Hercegovine (15-17. stoljeće): forma, jezik i stil." Anali Gazi Hüsrev-begove biblioteke (sy. 9-10, s. 1724), Sarajevo: Gazi Husrev-begova biblioteka.

Muvekit, S. S. H. (1999). Povijest Bosne 1-2. (A. Polimac at al. Trans.). Sarajevo: El-Kalem.

Nametak, F. (1998). (Ed.) Katalog arapskih, turskih, perzijskih i bosanskih rukopisa. Svezak 4. London: "Al-Furqân” Fondacija za İslâmsko naslijeđe, Sarajevo: Rijaset Islamske zajednice u BiH.

, (2000). "Važniji legati u rukopisnom fondu Gazi Hüsrev-begove biblioteke u Sarajevu." In E. Kujundžić (Ed.) Gazi Hüsrev-begova biblioteka: Pet stoljeća u misiji bošnjačke kulture, (s. 166-174), Sarajevo: Gazi Hüsrev-begova biblioteka \& El-Kalem.

Neumann, Ch. K. (2005). "Üç tarz-1 mütalaa: Yeniçağ Osmanlı Dünyasında kitap yazmak ve okumak." Tarih ve Toplum: Yeni Yaklaşımlar, (sy. 1 (Bahar), s. 51-76), İstanbul: İletişim Yayınları.

Özen, Ş. (2011). "Teftâzânî.” Türkiye Diyanet Vakfi İslâm Ansiklopedisi, (XXX, s. 299-308), İstanbul: Türkiye Diyanet Vakfı Yayınları.

Pelc, M. (2002). Pismo-Slika-Knjiga: Uvod u povijest informacijske kulture. Zagreb: Golden marketing.

Popara, H. \& Z. Fajić (2000) (Ed.) Katalog Arapskih, turskih, perzijskih $i$ bosanskih rukopisa. Svezak 7. London: "Al-Furqân" Fondacija za İslâmsko naslijeđe, Sarajevo: Rijaset Islamske zajednice u BiH.

Spaho, F. (2000). “Gazi Hüsrev-begova knjižnica.” In E. Kujundžić (Ed.) Gazi Hüsrev-begova biblioteka: Pet stoljeća u misiji bošnjačke kulture, (s. 818), Sarajevo: Gazi Hüsrev-begova biblioteka \& El-Kalem.

Stipčević, A. (1984). "Struktura bibliotečkih fondova u Hrvatskoj u 15. i 16. stoljeću." Slovo (sy. 34, s. 269-282), Zagreb: Staroslavenski institut.

Šabanović, H. (1973). Književnost muslimana BiH na orijentalnim jezicima. Sarajevo: Svjetlost.

Šukrić, N. (2000). “Gazi Hüsrev-begova biblioteka: Doprinos vakufljene knjige obrazovnom procesu kod nas.” In E. Kujundžić (Ed.) Gazi Hüsrev-begova biblioteka: Pet stoljeća u misiji bošnjačke kulture, 125-151. Sarajevo: Gazi Hüsrev-begova biblioteka \& El-Kalem.

Traljić, M. (1978). "Hafizi-kutubi Gazi Hüsrevbegove biblioteke." Anali Gazi Hüsrev-begove biblioteke, (sy. 5-6, s. 45-54), Sarajevo: Gazi Husrevbegova biblioteka. 
, (2000). "Iz prošlosti Gazi Hüsrev-begove biblioteke." In E. Kujundžić (Ed.) Gazi Hüsrev-begova biblioteka: Pet stoljeća u misiji bošnjačke kulture, (s. 112-115). Sarajevo: Gazi Hüsrev-begova biblioteka \& El-Kalem.

Usta, İ. (2011). “Avusturya Milli Kütüphanesi'ndeki Arapça Grameri İle İlgili Elyazmalar1." Journal of Intercultural and Religious Studies (sy. 1, s. 107117).

Yüksel, E. (1992). "Birgivî.” Türkiye Diyanet Vakfi İslâm Ansiklopedisi, (VI, s. 191-194), İstanbul: Türkiye Diyanet Vakfı Yayınları.

${ }^{1}$ Saraybosna olarak gelişen yerleşimin 15. yüzyılda kasabaya dönüşmesi, İsâ Bey İshâkzâde'nin (ö. 875/1470) büyük katkısı olmuștur. 1457 civarında buraya bir cami inşa ettirmiş ve Sultan Mehmed II'ye adamıştır. Caminin adı Hünkariye olmuştur. Cemâziye'l-âhir 866 (1 Şubat-3 Mart 1462) tarihli vakfiyesinden anlaşıldığı gibi İsâ Bey İshâk-zâde burada küçük bir saray, bunun yanısıra köprü, tekke, hamam, han inşa ettirmiştir. 1464-1470 yılları arasında Bosna sancakbeyi vazifesinde bulunmuştur. Vakfiyesi Saraybosna Gazi Hüsrev Bey Kütüphanesinde A-4341 numarası altında kayıtlı bulunmaktadır.

2 Bkz. Śabanović, 1973, s. 487; Kemura, 2000, s. 238. Kaynakların birinde kütüphane binasının 1172 (1758-59) yılında yapıldığ 1 söylenir. Bkz. Muvekit, 1999, c. I, s. 531.

${ }^{3}$ Hünkâriye'nin bölgedeki söyleyişidir. Bkz. Filan, 2011, s. 76.

${ }^{4}$ Şehdî Osmân Efendi 1757-58 yıllarında Rusya sefiri görevinde bulunmuştur. Bu görevi tamamlayıp İstanbul'a döndükten sonra Saraybosna'daki kütüphanesiyle meşgul olduğu anlaşılmaktadır.

${ }^{5}$ Burada zikredilen bağışların ilki 66 no'lu Şer'iye Sicil'in 207. sayfasında, diğeri 69 no'lu Şer'iye Sicil'in 82. Sicilleri Gazi Hüsrev Bey Kütüphanesi'nde bulunmaktadır.

${ }^{6}$ Şer'iye Sicili'nde kaydedilmiş bulunan vasiyetnameye göre, Saraybosna kadılarından Sîmzâde Abdulkerîm sayfasında kaydedilmiştir. Not no. 5'te adı geçen yazıda bağışlanan kitapların başlıkları, Şer'iye Sicilleri'nde kaydedildikleri şekilde Arap harfleriyle iki liste halinde verilmiştir. Günümuze kadar korunan Saraybosna Şer'iye Efendi (ö. 1177/1763) vakfettiği maldan bir medresenin yapılmasını vasiyet etmiştir. 1189/1775 yılında öğretime açılan medrese kurucusunun adı altında bilinmektedir (Kasumović, 1999, s. 180). Avusturya komutanlarından Eugen Savoyski tarafından 1679 'da Bosna bölgesine yapılan saldırıda çok büyük zarar gören Saraybosna'da üç medrese tamamen yıkılmıştır. Bunun üzerine 18. yüzyılda yeni eğitim müesseseleri kurulmuştur ve bunlardan biri Sîmzâde Abdulkerîm Efendi medresesidir.

7 Vakfiyesi Gazi Hüsrev Bey Kütüphanesi'nde bulunumaktadır (Fajić, 1983, s. 28). Abdülkâdir Muzafferî'nin ölüm tarihini tespit edemedik.

${ }^{8}$ Kantamirî Abdullâh Efendi kütüphanenin kurulduğu aynı yılda vefat etmiştir. Mollâ Mustafâ Başeski Mecmûası'nın Vefayât bölümünde Kantamirî Abdullâh Efendi hakkında şu kayıt düşmüştür: Vâ'iz idi, müderris idi, mahkemede başkâtib idi, pek ihtiyâr idi (Filan, 2011, s. 260).

${ }^{9}$ Saraybosna'da 18. yüzyılda kurulan medreselerden biridir. Belgelerde Mısrîzâde Medresesi veya Atmeydan Medresesi adları altında zikredilmektedir. Mısır'da hayatını geçiren Boşnak asıllı Hacı İsmâil Efendi tarafından 1712 yılında yapılmıştır. Banisi, vakıfıyla 
ilgili işlerini takip etmek amacıyla dönemin Saraybosna muderrisi Hacı Hüseyin Muzafferî'yi (ö. 1133/1721) tayin etmiştir (Kasumović, 1999, s. 177).

${ }^{10}$ Dönemin tarihçilerinden Vladimir Skarić, bu kültür anıtının yıkılması için "barbarlık" demiştir (Mujezinović, 1973, s. 45; ayrıca bkz. Spaho, 2000, s. 10).

${ }^{11}$ Gazi Hüsrev Bey Kütüphanesi metnin devamında GHBK kısaltmasıyla gösterilecektir.

${ }^{12}$ GHBK'nin mekân değiştirmeleri hakkında bkz. Traljić, 1978, s. 45.

${ }^{13}$ Kitabe metni şoyledir: Bismillahirrahmânirrahîm. Fî-hâ kütübün kayyimetün. Sene 1173 (Mujezinović, 1973, s. 45). 1970 y1lında Anali Gazi Husrev-begove biblioteke dergisinin yayını başlatıldığında, bu kitabe metni, kapak dizaynında dekorasyon olarak kullanılmıştır. 2001 yılında Anali dergisinin 19-20 sayısı çıktığında kapağına yeni bir dizayn verilmiştir.

${ }^{14}$ Kataloglamada yazma eserler içeriklerine göre gruplandırılmıştır. İçinde birden fazla konuya giren eserleri barındıran mecmûalara gelince, bunların gruplandırılması ilk eserin içeriğine göre yapılmıştır.

${ }^{15}$ Edebiyat alanına giren kitaplar Kataloğ'un 4. cildindedir. Buradan Dîvân-i Nevâ' i Ahmed Paşa, Dîvân-i Seyyid Vehbî, Dîvân-i 'Âsım gibi dîvânlar ile Şerh-i Kasîde-i bürde, Şerh-i Bûstân, Şerh-i Gülistân-i Sa 'dî̀, Yûsuf ü Züleyhâ gibi edebî eserlerin Şehdî Koleksiyonu'nda bulunduğu görülmektedir.

${ }^{16}$ Medreselerde Arapça oğretiminde okutulan kitaplar, Kevâkib-i Seb'a risalesinde verilen bilgilere dayanarak hazırlanmış, (Hazer, 2002, s. 274-293) adlı çalışmasına göre sınıflandırılmıştır. (Ayrıca bkz. Fazlıoğlu, 2005, s. 115-173).

${ }^{17}$ El yazmalarının her biri için Gazi Hüsrev Bey Kütüphanesi Kataloğu'ndaki yeri bu şekilde verilecektir (Kataloğ'un ilgili cildini hazırlayanın adı, yayın yılı, sayfa no'su).

${ }^{18}$ Bazı araştırmacılar müellifin adını İsâ Mehmed es-Sirâvî ya da İsâ Mehmed es-Sabrevî olarak okumuşlardı (Jahić, 2000, s. 14).

${ }^{19}$ Yukarıda zikredildiği gibi, Radiyeddîn Muhammed b. Hasan el-Esterâbâdî, eş-Şâfiye fí'ssarf eserinin de şarihidir.

${ }^{20}$ Katalog'da 1544 yılı verilmiştir (Jahić, 1999, s. 373).

${ }^{21}$ Gazi Hüsrev Bey Kütüphanesi Kataloğu'nun 7. cildini hazırlayan Popara \& Fajić'in (2000, s. 18) tespitlerine göre, Kemâl b. 'Alî b. İshâk adında müellif sadece Türkiye Yazmalar Toplu Kataloğu'nda (07/V, sira sayıs1 3521) zikredilir.

${ }^{22}$ Eserin yazarı olarak bir kaynakta Hâlid el-Ezherî anıldığı halde diğer kaynaklar ve yazma katalogları bu bilgiyi doğrulamamaktadır (Jahić, 1999, s. 382).

23 Bayram Gazi adında medrese O. Oğuzhan Arslanoğlu tarafından kaleme alınmış "Nasrullah Kadı ve Nasrullah Kadı Camii Etrafında Kurulmuş Medresler" başlıklı çalışmasında şu şekilde zikredilir (Arslanoğlu, 2016, s. 250): "Bayram Gazi Medresesi'nin bugün Kastamonu'ya $100 \mathrm{~km}$ mesafede bulunan sahil ilçesi olan Bozkurt ilçesine $5 \mathrm{~km}$ mesafede bulunan bugün de Bayram Gazi adıyla anılan köyde olma ihtimali yüksektir ve burada birde türbe bulunmaktadır. Bu türbe de Bayram Gazi Türbesi olarak bilinmektedir".

${ }^{24}$ Kullandığımız Katalog'da müellifin adı at-Tûsiyawî veya at-Tûsî ya da at-Tûsawî olarak verilmektedir (Jahić, 1999, s. 168). Türkiye Diyanet Vakfı İslam Ansiklopedisi'de "Mutarrizî" maddesine göre Hulâsatū'l-İ'râb'in müellifi Hacı Baba et-Tosyavî'dir (Çöğenli, 2006, s. 376).

25 Katalog'da Ziyâuddîn el-Mekkî şeklinde adı verilen müellifin ölüm tarihini tespit edemedik.

${ }^{26}$ el-Mukaddime el-âcurrûmiyye üzerine kaleme alınmış şerhler üzerine bkz. Kılıç, 1999, s. 295. 
${ }^{27}$ Medrese geleneğinde Arapça temel derslerden sayılırdı ve daha başlangıç ve orta seviyelerde okutulmuştur. Yüksek seviyeye ait ders müfredatında, meselâ, Arapçanın şekil bilgisi, cümle bilgisi ve mantık gibi öğrenciyi yüksek ilimler için hazırlayan dallardan kitaplara rastlanmamaktadır (Shahab \& Filipović, 2004, s. 191 ile s. 207).

${ }^{28}$ Osmanlı döneminde Bosna eyaletinde eğitim-öğretim veren müesseseler hakkında bkz. Kasumović, 1999.

${ }^{29}$ Şuglî Osmân Efendi'nin bu çalışmaları hakkında bkz. Filan, 2017, s. 159-188.

${ }^{30}$ Dâvûd el-Karsî: "Bazı arkadaşlarım benden emsile-i muhtelifeyi Türkçe-Arapça tabirlerle şerhetmemi, dağınık duran kuralları toplamamı istediler" şeklindeki sözlerle sebebi telifi açıklamıştır (Hazer, 2002, s. 287).

${ }^{31}$ El yazması eserler kütüphanelerinde en çok rastlanan Emsile-i muhtelife şerhlerinin sayısı 13 'tür. Bunlardan 6's1 Türkçedir (Durmuş, 1995, s. 167; Hazer, 2002, s. 286).

32 Bilindiği gibi, müellifin okuyucudan kendisi için dua etmeyi dilemesi yaygın bir uygulamaydı ve Neumann bunu o dönemde "metin kaleme alınmanın üç ana saikasından biri” olarak ileri sürmektedir (Neumann, 2005, s. 70 ve devamı).

${ }^{33}$ Bununla ilgili bkz. Neumann, 2005, s. 59-63.

${ }^{34}$ Bugün kütüphanede bulunan 12 nüshadan 3'i 18. yüzyılda, 2'si 19. yüzyılda olmak üzere toplam beş adedi Bosna'da istinsah edilmiştir (Jahić, 1999, s. 435-442). Bundan, eserin bu bölgede çok okunduğu anlaşılmaktadır.

${ }^{35}$ Muhammed Şevkî Efendi Kurt (1879-1963), Bosna-Hersek'te 20. yüzyılın ilk çeyreğinde bilim-kültür hayatına damga vuran âlimlerden biriydi. Kendisi önce Banya Luka'da (1914-1925), daha sonra Tuzla'da (1925-1933) müftü görevinde bulunmuştur. Bkz. "Muhamed Šefket ef. Kurt (1879-1963), muftija u Banja Luci i Tuzli." Porodica Kurt iz Mostara. https://porodica-kurt.com/muhamed-sefket-kurt/ (Erișim tarihi: 25/3/2021).

${ }^{36}$ Kemura, Mollâ Mahmûd'un Şehdî Kütüphanesi'nde hâfız-1 kütüp olduğunu yazmıştır (Kemura, 2000, s. 243).

${ }^{37}$ Mollâ Mustafâ Başeski Mecmua'sının Vefayât bölümünde isimlerini kayda geçirdiği iki kişi için hâfiz-ı kütübhâne, bir kişi için kütübhâneci yazmıştır (Filan, 2011, 238, 251 ve 240). Ne yazık ki hangi kütüphane(ler)de görev yaptıklarına dair bize bilgi bırakmamıştır. Bu üç kişiden Foyniçevî Hacı Mehmed Efendi'nin (ö. 1184/1770-71) sâbık müftî, hâfız-ı kütübhâne, vâ 'iz ve müderris olduğunu da yazmıştır.

38 Dupniçeli Ahmed Efendi, medresede müderris olduğu senede Gazi Hüsrev-Bey Hânkâhı'nın başına getirilmiş, yaklaşık 10 yıl boyunca Saraybosna'nın en önemli iki eğitim-bilim müessesesinin başında bulunmuştur. 1777 yılından itibaren hânkâhın müderrisi Memed Râzî Efendi Velîhocaoğlu olmuş, Ahmed Efendi Dupniçeli medresedeki görevine devam etmiştir (Kreševljaković, 1932, s. 149).

39 Bugün Gazi Hüsrev Bey Kütüphanesi'nde el-I'râb 'an kavâ 'idi'l-i 'râb'ın çok sayıda nüshası bulunmaktadır. Muvassilü't-tullâb ilâ kavâ 'idi'l-i ' $r a ̂ b$ '

40 Yukarıdaki listede gösterildiği gibi, Merâhü'l-ervâh'ın bir şerhi ana koleksiyonda yer almıştır. 